\title{
Water-table height and microtopography control biogeochemical cycling in an Arctic coastal tundra ecosystem
}

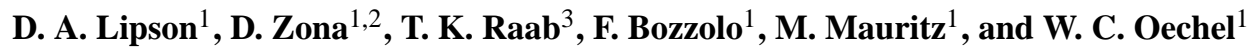 \\ ${ }^{1}$ San Diego State University, San Diego, CA, USA \\ ${ }^{2}$ University of Antwerp, Belgium \\ ${ }^{3}$ Stanford University, Stanford, CA, USA \\ Correspondence to: D. A. Lipson (dlipson@sciences.sdsu.edu)
}

Received: 5 June 2011 - Published in Biogeosciences Discuss.: 6 July 2011

Revised: 23 December 2011 - Accepted: 5 January 2012 - Published: 31 January 2012

\begin{abstract}
Drained thaw lake basins (DTLB's) are the dominant land form of the Arctic Coastal Plain in northern Alaska. The presence of continuous permafrost prevents drainage and so water tables generally remain close to the soil surface, creating saturated, suboxic soil conditions. However, ice wedge polygons produce microtopographic variation in these landscapes, with raised areas such as polygon rims creating more oxic microenvironments. The peat soils in this ecosystem store large amounts of organic carbon which is vulnerable to loss as arctic regions continue to rapidly warm, and so there is great motivation to understand the controls over microbial activity in these complex landscapes. Here we report the effects of experimental flooding, along with seasonal and spatial variation in soil chemistry and microbial activity in a DTLB. The flooding treatment generally mirrored the effects of natural landscape variation in water-table height due to microtopography. The flooded portion of the basin had lower dissolved oxygen, lower oxidation-reduction potential (ORP) and higher $\mathrm{pH}$, as did lower elevation areas throughout the entire basin. Similarly, soil pore water concentrations of organic carbon and aromatic compounds were higher in flooded and low elevation areas. Dissolved ferric iron (Fe(III)) concentrations were higher in low elevation areas and responded to the flooding treatment in low areas, only. The high concentrations of soluble Fe(III) in soil pore water were explained by the presence of siderophores, which were much more concentrated in low elevation areas. All the aforementioned variables were correlated, showing that $\mathrm{Fe}$ (III) is solubilized in response to anoxic conditions. Dissolved carbon dioxide $\left(\mathrm{CO}_{2}\right)$ and methane $\left(\mathrm{CH}_{4}\right)$ concentrations were higher in low elevation areas, but showed only subtle and/or seasonally dependent effects of flooding. In anaerobic laboratory incubations, more $\mathrm{CH}_{4}$ was produced
\end{abstract}

by soils from low and flooded areas, whereas anaerobic $\mathrm{CO}_{2}$ production only responded to flooding in high elevation areas. Seasonal changes in the oxidation state of solid phase $\mathrm{Fe}$ minerals showed that net $\mathrm{Fe}$ reduction occurred, especially in topographically low areas. The effects of Fe reduction were also seen in the topographic patterns of $\mathrm{pH}$, as protons were consumed where this process was prevalent. This suite of results can all be attributed to the effect of water table on oxygen availability: flooded conditions promote anoxia, stimulating dissolution and reduction of $\mathrm{Fe}(\mathrm{III})$, and to some extent, methanogenesis. However, two lines of evidence indicated the inhibition of methanogenesis by alternative e- acceptors such as $\mathrm{Fe}$ (III) and humic substances: (1) ratios of $\mathrm{CO}_{2}: \mathrm{CH}_{4}$ evolved from anaerobic soil incubations and dissolved in soil pore water were high; (2) $\mathrm{CH}_{4}$ concentrations were negatively correlated with the oxidation state of the soluble Fe pool in both topographically high and low areas. A second set of results could be explained by increased soil temperature in the flooding treatment, which presumably arose from the increased thermal conductivity of the soil surface: higher $\mathrm{N}$ mineralization rates and dissolved $\mathrm{P}$ concentrations were observed in flooded areas. Overall, these results could have implications for $\mathrm{C}$ and nutrient cycling in high Arctic areas where warming and flooding are likely consequences of climate change.

\section{Introduction}

The height of the water table controls the balance of anaerobic and aerobic processes in wetlands and other periodically flooded systems (Blodau, 2002; Reddy and DeLaune, 2008; Kögel-Knabner et al., 2010). Surface water restricts 
the diffusion of oxygen $\left(\mathrm{O}_{2}\right)$, creating anoxic conditions that promote anaerobic processes such as methane $\left(\mathrm{CH}_{4}\right)$ production or anaerobic respiration using a variety of alternative electron $\left(\mathrm{e}^{-}\right)$acceptors, such as nitrate $\left(\mathrm{NO}_{3}^{-}\right)$, manganese $(\mathrm{Mn}(\mathrm{IV}))$, iron (Fe(III)), humic substances and sulfate $\left(\mathrm{SO}_{4}^{2-}\right)$. Surface water can also have other important physical effects on soils; for example in soils with thick surface organic layers, increased water content greatly increases thermal conductivity (Kujala et al., 2008; O'Donnell et al., 2009), and so flooding or ponding can lead to deeper heat penetration and active layer depth in soils with permafrost (Brown, 1967; Shiklomanov et al., 2010).

Northern permafrost soils contain vast reservoirs of carbon (C), and could be a major source for carbon dioxide $\left(\mathrm{CO}_{2}\right)$ and $\mathrm{CH}_{4}$ in the next century as a result of climate warming (Schuur et al., 2008; Tarnocai et al., 2009). In the past century, high latitude sites have warmed faster than the rest of the planet (IPCC, 2007), and this warming trend has already caused significant increases in $\mathrm{CH}_{4}$ production from Arctic ecosystems (Bloom et al., 2010). However the $\mathrm{C}$ balance of Arctic ecosystems has shown complex responses to climate change over the past few decades (Oechel et al., 1993; Oechel et al., 2000). Increased plant productivity could help offset losses of soil C, particularly if rates of $\mathrm{N}$ mineralization increase in response to warming (Shaver et al., 1992). On the other hand, higher $\mathrm{N}$ availability can also stimulate decomposition and lead to further losses of soil C (Mack et al., 2004). The responses of any given Arctic ecosystem to climate change, in particular the rates of ecosystem $\mathrm{CH}_{4}$ and $\mathrm{CO}_{2}$ production, will likely depend on local factors, such as microtopography and soil properties, and how they influence the responses of nutrient cycling rates and the availability of alternative $\mathrm{e}^{-}$acceptors to changes in temperature and hydrology.

The water table in many high Arctic ecosystems is affected by complex microtopographic patterns that arise from the formation of ice wedge polygons (Brown, 1967). Over many freeze-thaw cycles, ice wedges form in the soil, pushing up regions that become the rims of low-centered polygons, causing water to accumulate in the lower polygon centers. The ice wedges under the rims of these features can melt and subside, creating high centered polygons (Billings and Peterson, 1980). The presence of this complex spatial pattern complicates predictions of the ecosystem response to climate change. Previous studies have shown that the net effect of water- table manipulations on the $\mathrm{C}$ cycle depend on the plant community and location on the landscape (Updegraff et al., 2001; Strack et al., 2006; Strack and Waddington, 2007). Furthermore, climate change will have complex effects on the hydrology of northern soils. As northern latitudes have warmed, areas of discontinuous permafrost have degraded, leading to draining of lakes; however in areas of continuous permafrost, lake coverage has increased as a result of themokarst activity (Smith et al., 2005). Predicting ecosystem responses to climate change in the Arctic requires an understanding of how water table and microtopography control biogeochemical cycling and microbial processes such as respiration and methanogenesis.

Drained thaw lake basins (DTLB's) make up a significant portion of the landscape of the Arctic Coastal Plain (Billings and Peterson, 1980; Hinkel et al., 2003; Bockheim et al., 2004). These features originate as lakes that drain due to various erosional processes and become vegetated. As these DTLB's develop over the course of hundreds to several thousand years, ice wedge polygons create complex topography within these basins. One such DTLB near Barrow, Alaska was the location of a large scale water-table manipulation ("Biocomplexity") experiment (Zona et al., 2009; Olivas et al., 2010). Previous work at the Biocomplexity site showed that much of the basin is prone to anoxia, and that dissimilatory $\mathrm{Fe}(\mathrm{III})$ reduction is a particularly important anaerobic process that contributes significantly to the ecosystem C budget (Lipson et al., 2010). This process is generally thought to competitively inhibit methanogenesis by providing a more thermodynamically favorable respiratory pathway (Roden and Wetzel, 1996; Blodau, 2002; Bond and Lovley, 2002; Küsel et al., 2008; Jerman et al., 2009). And while $\mathrm{CH}_{4}$ production has been studied in the Arctic Coastal Plain near Barrow, AK (Rhew et al., 2007; Zona et al., 2009; von Fischer et al., 2010), no studies have yet explored how Fe(III) reduction interacts with $\mathrm{CH}_{4}$ production in this ecosystem. Additionally, our understanding of $\mathrm{Fe}$ (III) reduction in this ecosystem has yet to be integrated with a study of fine-scale spatial variability in microtopography and water-table height.

The goal of this study was to understand the effects of natural and experimental variation in water-table height on soil chemistry, microbial respiratory processes and nutrient cycling in polygonized tundra of the Arctic Coastal Plain in Northern Alaska. The motivation was to understand potential responses to climate change but also the controls of microtopography and water-table height on the current functioning of this ecosystem.

\section{Methods}

\subsection{Site description and flooding treatment}

This research was carried out in a DTLB in the Barrow Environmental Observatory near Barrow, Alaska $\left(71.32^{\circ} \mathrm{N}\right.$, $\left.156.62^{\circ} \mathrm{W}\right)$. The DTLB is classified as medium-aged, having drained from 50-300 years in the past (Hinkel et al., 2003). Low-centered polygons have formed over much of the basin, particularly in the central and north sections. Vegetation is dominated by mosses (Sphagnum spp.), sedges (Carex aquatilis, Eriophorum spp.), and grasses (Dupontia fisheri, Arctophila fulva), with mosses dominating topographically high areas such as polygon rims and Carex dominating low areas such as polygon centers (Zona et al., 2009; Olivas et al., 2010). The soils within the basin are classified as aquahaplels, orthels and histoturbels, with an organic horizon 
( $\sim 12-15 \mathrm{~cm}$ thick) overlaying a silty mineral layer. The active layer is typically about $30 \mathrm{~cm}$ deep (Shiklomanov et al., 2010). The water table manipulation experiment at this site has been described in detail previously (Zona et al., 2009; Lipson et al., 2010; Olivas et al., 2010). Briefly, the roughly elliptical basin (about $1.5 \mathrm{~km}$ long) was divided into three sections by plastic dikes buried in the permafrost. The north section was designated as the flooded treatment, the central as the draining treatment and the south as the control. Water was pumped from the central section into the north section. However this produced only modest alterations of the water table and so additional water was pumped into the north section from nearby Cakeeater Lake. This treatment was performed during the summers of 2008 and 2009. The draining treatment was very subtle in its effect on water table relative to the flooding treatment, and the control (south) and drained (central) areas were indistinguishable in the response variables measured in this study. Therefore the two nonflooded areas were pooled for most purposes in this study. Raised boardwalks were installed across each of the three sections, creating $300 \mathrm{~m}$ long transects. All measurements presented here occurred along these three transects. Elevation was recorded with a differential GPS (Trimble R7 and R8) every $2 \mathrm{~m}$ along each transect, and interpolated linearly as needed. For spatially intensive data (see below), elevation classes were defined by rounding elevation values to the nearest $0.1 \mathrm{~m}$. Most of the data presented here were collected during the summer of 2009, the second year of the treatment. Additional data were collected before the treatment was initiated (2006-2007), the first treatment year (2008), and the summer after the flooding treatment was halted (2010).

\subsection{Soil electrochemistry}

Measurements of $\mathrm{pH}$ and oxidation-reduction potential (ORP) were taken at $10 \mathrm{~cm}$ depth using a portable meter (Thermo-Orion). Electrodes were inserted into the soil after a small incision was made with a serrated knife. These measurements were made repeatedly at a set of permanent plots chosen (based on visual examination of each site) to represent high and low areas of the landscape within each transect (three high and three low areas per transect, 18 total). These were the same locations used for soil pore water sampling described below. Additionally, more spatially intensive measurements were made on a subset of sampling days. ORP measurements are reported as raw values relative to the internal $\mathrm{Ag} / \mathrm{AgCl}$ reference electrode. Dissolved $\mathrm{O}_{2}$ was measured using a microelectrode and portable picoammeter (Unisense). The $\mathrm{O}_{2}$ electrode was used to find the approximate location of the transition zone between oxic and anoxic horizons ("oxycline"). Because the electrode is only $5 \mathrm{~cm}$ long, if the oxycline lay deeper than $5 \mathrm{~cm}$, it was recorded whether the dissolved $\mathrm{O}_{2}$ concentration at $5 \mathrm{~cm}$ depth was suboxic ( $<50 \%$ saturation) or oxic ( $>50 \%$ saturation), and assigned non-parametric values 6 or 7 , respectively.

\subsection{Soil water chemistry}

Soil water was collected from $10 \mathrm{~cm}$ long, porous soil moisture samplers (Rhizon, Ben Meadows) inserted into the soil at an angle, to capture $0-5 \mathrm{~cm}$ soil pore water, or vertically, to capture water at 5-15 cm depths. The deeper depths were only accessible for a limited number of dates later in the season. The soil moisture samplers were installed in six locations on each transect, split between high and low areas as described above. Water samples were collected through hypodermic needles into evacuated tubes (BD Vacutainers). On most dates, two sets of water samples were collected; one was acidified with a drop of $1 \mathrm{M} \mathrm{HCl}$ to preserve the oxidation state of dissolved Fe species. The other set, reserved for dissolved gas analysis, was not acidified and was sealed in Bitran bags to reduce gas exchange with the atmosphere. All water samples were kept refrigerated until analysis.

Acidified water samples were analyzed for dissolved $\mathrm{Fe}^{2+}$ and $\mathrm{Fe}^{3+}$ using 1,10-phenanthroline, as described previously (Analytical Methods Committee, 1978; Lipson et al., 2010). As an index of dissolved aromatic compounds, absorbance at $260 \mathrm{~nm}$ (A260) was measured on a standardized volume $(200 \mu \mathrm{L})$ in UV-transparent microtiter plates using a microplate reader (SpectraMax 190, Molecular Devices). Dissolved organic $\mathrm{C}$ was measured using an assay based on $\mathrm{Mn}(\mathrm{III})$ as described earlier (Bartlett and Ross, 1988; Lipson et al., 2010).

Ammonium $\left(\mathrm{NH}_{4}^{+}\right)$was analyzed using a phenolatehypochlorite method and free amino-N, using a ninhydrin method (Lipson et al., 1999). Ninhydrin also reacts with $\mathrm{NH}_{4}^{+}$so these values were subtracted from ninhydrin-active $\mathrm{N}$ to yield amino-N. Phosphate $\left(\mathrm{PO}_{4}\right)$ was analyzed with a paramolybdate-ascorbate method (Kuo, 1996). All these assays were scaled down for use in a microplate reader.

The presence of siderophores (biologically produced organic molecules capable of binding Fe(III) with high affinity) was assayed using a colorimetric assay based on the dye, chrome azurol S (Alexander and Zuberer, 1991). This dye forms a blue compound when coordinated with Fe(III), and so sequestration of $\mathrm{Fe}$ (III) from the dye complex by siderophores causes a decrease in the blue color. To remove interference from dissolved Fe(III) in the water samples, it was necessary to dilute samples ten-fold and increase the $\mathrm{FeCl}_{3}$ concentration in the dye reagent to $250 \mu \mathrm{M}$. Deferoxamine mesylate (Sigma-Aldrich) was used as a standard.

Dissolved $\mathrm{CH}_{4}$ and $\mathrm{CO}_{2}$ were analyzed in non-acidified water samples. Flasks $(25 \mathrm{~mL})$ with butyl stoppers were flushed with $\mathrm{N}_{2}$ gas for $1 \mathrm{~min}, 1.0 \mathrm{~mL}$ soil pore water was injected by syringe, allowed to equilibrate at $22^{\circ} \mathrm{C}$ overnight, and the headspace was sampled by syringe and analyzed by gas chromatography (Model 8610C with methanizer and flame ionization detector, SRI Instruments, Torrance, CA). Original dissolved gas concentrations were calculated from the headspace concentrations and Henry's law constants for the two gases. 


\subsection{Microbial activity and biomass}

On three dates in 2009, soil cores were collected to a depth of $15 \mathrm{~cm}$ using a serrated knife, sealed in two layers of Bitran specimen bags, and frozen. Cores were weighed, and the volume of the frozen cores wrapped tightly in plastic wrap was determined by displacement of water. Subsamples of these soils $(\sim 25 \mathrm{~g}$ wet weight) were placed in sealed mason jars with septa installed in the lids, and allowed to thaw under $\mathrm{N}_{2}$ gas overnight at $4{ }^{\circ} \mathrm{C}$. The following day the jars were again flushed with $\mathrm{N}_{2}$ gas to remove accumulated gases, syringe samples were taken at 6 and $24 \mathrm{~h}$ after this point, and analyzed by gas chromatography as described above. Other subsamples from these cores were subjected to chloroform fumigation-extraction for indices of microbial biomass $\mathrm{C}$ and $\mathrm{N}$. Organic $\mathrm{C}$ and ninhydrin-reactive $\mathrm{N}$ in these extracts were measured as described above. Subsamples were also used in proteolysis measurements: soils $(\sim 5 \mathrm{~g}$ wet weight $)$ were placed in tubes with $20 \mathrm{~mL}$ sodium acetate buffer $(50 \mathrm{mM}$, $\mathrm{pH}$ 5.0) with $1 \%$ bovine serum albumin (BSA) as a protein source, and $0.4 \mathrm{~mL}$ toluene to inhibit amino acid uptake. Samples and soil-free controls were incubated at $6{ }^{\circ} \mathrm{C}$ on a shaker for $16 \mathrm{~h}$. Samples were removed, remaining BSA was precipitated by heating at $95^{\circ} \mathrm{C}$ for $10 \mathrm{~min}$, and released amino acids were measured using the ninhydrin assay. Microbial biomass and proteolytic rates were also measured on soils collected in July 2008.

Seasonal changes in solid-phase Fe was determined by extracting frozen soils in $1 \mathrm{~N} \mathrm{H}_{2} \mathrm{SO}_{4}$ for $24 \mathrm{~h}$. The resulting extracts were diluted and assayed for $\mathrm{Fe}^{2+}$ and $\mathrm{Fe}^{3+}$ as described above.

A measure of $\mathrm{N}$ availability to plants was obtained by burying nylon bags with $10 \mathrm{~g}$ mixed bed ion exchange resins at a depth of $5 \mathrm{~cm}$. The resin was rinsed with copious amounts of distilled water before placing in the field, and replicate resin bags stored at $4{ }^{\circ} \mathrm{C}$ served as controls. Resin bags were placed in the soil at the beginning of July and collected in mid-August. Resin bags were extracted in $2 \mathrm{M} \mathrm{KCl}$, analyzed for $\mathrm{NH}_{4}^{+}$and $\mathrm{NO}_{3}^{-}$, and values from control bags were subtracted. This method was used in 2007 (before the flooding treatment) and again in 2009. Resin bags were installed near the same permanent plots referred to above (three high and three low locations in each transect).

\subsection{Statistical analysis}

Specific statistical tests used for each data set are described in the results section. These included general linear models (GLM), analysis of variance (ANOVA), analysis of covariance (ANCOVA), the Kruskal-Wallis test (for analysis of the non-parametric oxycline variable), as well as simple regression and correlation analysis. Systat (v. 12.0) was used for all analyses. P-values less than 0.05 are considered significant, while $0.1>\mathrm{P} \geq 0.05$ are referred to as marginally significant.

\section{Results}

\subsection{Flooding treatment}

The experimental basin increases in polygonization from south to north. This can be seen as a widening range of elevations from south to central to north treatment areas (Fig. 1a). The north includes areas with elevations as low as $1.5 \mathrm{~m}$, but these were omitted from the analysis so that a comparable range of elevations would exist between the flooded and reference areas. At any given time, water-table height was a function of microtopography, with lower elevation areas experiencing larger water-table heights and a disproportionately large effect of the flooding treatment (Fig. 1a). The effects of elevation $(F=103.8, P<0.001)$, treatment area $(\mathrm{N}, \mathrm{C}$ and $\mathrm{S})(F=38.0, P<0.001)$ and the interaction $(F=29.0, P<0.001)$ were all highly significant for this ANCOVA $\left(n=403, R^{2}=0.736\right)$.

In 2008 , the flooding treatment initially raised the average water-table height by $8.6 \mathrm{~cm}$ relative to non-flooded areas, reaching a maximum differential of $15.3 \pm 1.2 \mathrm{~cm}$ by the end of summer (data not shown) (Olivas et al., 2010). In 2009, the flooding treatment initially achieved an average water-table height $4.0 \pm 1.2 \mathrm{~cm}$ higher than the nonflooded treatment areas, reaching a maximum differential of $22.5 \pm 1.4 \mathrm{~cm}$ at the end of July (Fig. 1b). (Late in the summer of 2009, water was pumped into the south region to create an intermediate water table treatment; however, none of the data presented here were affected by this treatment). The wetter soils conducted heat more efficiently, leading to warmer temperatures in mid-summer (Fig. 1c). Averaged across all dates, temperatures measured in the flooding treatment were $1.0 \pm 0.1^{\circ} \mathrm{C}$ higher than in the unflooded treatments.

\subsection{Soil electrochemistry}

Soil ORP and $\mathrm{pH}$ were both controlled by water-table height (Fig. 2a, c), with more reducing and less acidic conditions in wetter areas. Accordingly, in ANCOVA, ORP was positively correlated $\left(R^{2}=0.287, F=68.2, P<0.001\right)$ and $\mathrm{pH}$ was negatively correlated $\left(R^{2}=0.388, F=118.6, P<\right.$ 0.001 ) with elevation, and for any given elevation, $\mathrm{pH}$ was higher $(F=100.1, P<0.001)$ and ORP lower $(F=71.9$, $P<0.001$ ) in the flooding treatment (Fig. 2b, d). The negative correlation between $\mathrm{pH}$ and ORP was highly significant (Table 1).

The seasonal pattern of ORP followed that of water table, becoming more oxic as water levels dropped (Fig. 3a, b). Despite this seasonal pattern and the overall negative correlation between $\mathrm{pH}$ and ORP, $\mathrm{pH}$ also increased during the early growing season, particularly in low elevation classes (Fig. 3c, d), corresponding to a period where reduction of solid phase Fe minerals was observed (Lipson et al., 2010), see Sect. 3.4 below. 
Table 1. Correlations among dissolved species in soil water and electrochemical measurements. The upper diagonal shows correlation coefficients (with those significant by Bonferroni test, $\alpha=0.05 / 21=0.0024$, in bold). Lower diagonal shows sample size for each correlation.

\begin{tabular}{llllllll}
\hline & $\mathrm{Fe} 3$ & $\mathrm{~A} 260$ & $\mathrm{DOC}$ & $\log \mathrm{CH}_{4}$ & $\log \mathrm{CO}_{2}$ & $\mathrm{pH}$ & $\mathrm{ORP}$ \\
\hline $\mathrm{Fe} 3$ & & $\mathbf{0 . 8 2 4}$ & $\mathbf{0 . 7 0 2}$ & $\mathbf{0 . 3 6 1}$ & $\mathbf{0 . 5 6 1}$ & $\mathbf{0 . 4 9}$ & $\mathbf{- 0 . 3 7 8}$ \\
$\mathrm{A} 260$ & 126 & & $\mathbf{0 . 7 9}$ & $\mathbf{0 . 4 0 1}$ & $\mathbf{0 . 5 9 3}$ & $\mathbf{0 . 5 3 8}$ & $\mathbf{- 0 . 4 7 1}$ \\
$\mathrm{DOC}$ & 102 & 102 & & 0.292 & $\mathbf{0 . 5 4 5}$ & 0.253 & $\mathbf{- 0 . 5 9 3}$ \\
$\log \mathrm{CH}_{4}$ & 73 & 73 & 51 & & $\mathbf{0 . 7 9}$ & $\mathbf{0 . 5 0 5}$ & $\mathbf{- 0 . 4 6}$ \\
$\log \mathrm{CO}_{2}$ & 73 & 73 & 51 & 73 & & $\mathbf{0 . 6 0 2}$ & $\mathbf{- 0 . 5 5 3}$ \\
$\mathrm{pH}$ & 126 & 126 & 102 & 73 & 73 & & $\mathbf{- 0 . 5 8 3}$ \\
$\mathrm{ORP}$ & 90 & 90 & 68 & 55 & 55 & 720 & \\
\hline
\end{tabular}

Table 2. Oxycline depth index. Values of 0-5 indicate the depth in $\mathrm{cm}$ at which dissolved $\mathrm{O}_{2}$ dropped to near-anoxic levels. Values of 6 and 7 are non-parametric indicators of suboxic $\left(<50 \% \mathrm{O}_{2}\right.$ saturation) and oxic ( $>50 \% \mathrm{O}_{2}$ saturation) conditions, respectively, at $5 \mathrm{~cm}$ depth. For the seasonal sampling (taken at fewer locations), values are means (and standard errors).

\begin{tabular}{lll}
\hline & Flooded & Unflooded \\
\hline $7 / 22-7 / 23$ intensive sampling \\
median & 3 & 7 \\
mean & 3.61 & 6.63 \\
se & 0.33 & 0.09 \\
$n$ & 49 & 75 \\
\hline \multicolumn{2}{l}{ Seasonal sampling } \\
$6 / 29 / 2009$ & $4.17(0.91)$ & $4.17(0.75)$ \\
$7 / 15 / 2009$ & $3.83(1.45)$ & $4.93(0.62)$ \\
$7 / 24 / 2009$ & $5(1.22)$ & $7(0)$ \\
$7 / 29 / 2009$ & $4.17(1.28)$ & $6.67(0.26)$ \\
\hline
\end{tabular}

Conditions in the flooded treatment were generally anoxic at $5 \mathrm{~cm}$ depth or shallower throughout the measurement period (Table 2). In the unflooded areas conditions generally became oxic in the upper $5 \mathrm{~cm}$ by late July, as the water table had dropped below $5 \mathrm{~cm}$ depth by this time (Fig. 1b). The effect of flooding on the oxycline depth was highly significant for the spatially-intensive 22-23 July data set (KruskalWallis test $P<0.001)$. In the GLM analysis of these data (dfe $=120)$, elevation $(F=48.0, P<0.001)$ and flooding $(F=54.8, P<0.001)$ were also highly significant. For the less spatially-intensive seasonal sampling, the flooding effect was significant in a two-way ANOVA with date and flooding as categorical factors $(P=0.016)$.

Trends in $\mathrm{pH}$ and ORP disappeared or reversed in the year following the water manipulation (2010). Before the flooding treatment was initiated and after it ceased, soil $\mathrm{pH}$ was slightly lower and ORP slightly higher in the north ("flooded") section of the experimental basin (Table 4).

\subsection{Soil water chemistry}

Soil pore water concentrations (from $0-5 \mathrm{~cm}$ depth) of aromatic compounds (A260), DOC, Fe(III), $\mathrm{NH}_{4}^{+}$, amino-N and $\mathrm{PO}_{4}$, all declined exponentially throughout the season (Fig. 4). Therefore data were log-transformed to linearize this trend, and ANCOVA were run using date as a continuous variable and topography and flooding as factors (no significant interactions with date were found in these models). In the case of $\mathrm{PO}_{4}$, the three-way ANOVA (with date coded categorically) had a significantly lower corrected Aikake information criterion $\left(\mathrm{AIC}_{c}\right)$ than the ANCOVA, and so these results are reported instead of the ANCOVA (Table 3). Significance of effects did not vary between the two model types, with one exception (see results for $\mathrm{NH}_{4}^{+}$below). Because the effects of flooding and topography were generally independent of date, to simplify presentation for most variables only the grand means of each treatment category are shown in Fig. 5. In the case of $\mathrm{NH}_{4}^{+}$, certain dates appeared to have a disproportionate effect, and so the seasonal patterns for flooded and unfloooded treatments are shown (Fig. 5h).

A260, DOC, and Fe(III) followed similar trends (Fig. 5ac) and were highly correlated (Table 1). All were significantly higher in low elevation areas (Table 3). A260 was significantly higher in the flooding treatment; $\mathrm{Fe}$ (III) was significantly higher in low elevation areas of the flooded treatment (topography $\times$ flooding interaction). The effect of flooding on DOC was significant $(P=0.02)$, and while the response appeared to be driven by low elevation areas (Fig. 5b), the topography $\times$ flooding interaction was marginal $(P=0.098)$. The trends observed in A260 and Fe(III) during the flooding treatment were reversed in the years before and after the flooding treatment was in effect, with generally higher values in the areas used for the unflooded treatment (Table 4).

For two dates later in the season, soil water samples were also collected from deeper in the profile $(5-15 \mathrm{~cm})$. On these dates, dissolved $\mathrm{Fe}(\mathrm{III})$ concentrations and A260 values were significantly higher at depth, by factors of 2.65 and 2.36 , respectively (data not shown). Mean DOC concentrations were only 1.33 times higher at depth, and this difference was not statistically significant (data not shown). 
Table 3. Statistical tests (F-statistics and p-values) on the log-transformed water chemistry data (0-5 cm depth) presented in Figs. 5 and 6. For all but two variables, ANCOVA models were used with date as a continuous variable (see Fig. 4) and flooding treatment and topography as categorical effects. For $\mathrm{PO}_{4}$ and $\mathrm{CH}_{4}$, three-way ANOVA were used, with date coded categorically (these models had significantly lower $\mathrm{AIC}_{c}$ than the ANCOVA). No interactions with date were significant $(P<0.05)$ in any model. Topo $=$ topographic effect, dfe $=$ degrees of freedom in error. Significant effects are shown in bold, marginally significant effects $(0.05<P<0.1)$ are italicized.

\begin{tabular}{lcccccc}
\hline & & Date & Topo & Flooding & Topo $\times$ Flood & dfe \\
\hline Fe(III) & F & $\mathbf{2 6 . 1 2 7}$ & $\mathbf{9 2 . 9 9 4}$ & 0.243 & $\mathbf{8 . 3 4 5}$ & 121 \\
& p & $<\mathbf{0 . 0 0 1}$ & $<\mathbf{0 . 0 0 1}$ & 0.623 & $\mathbf{0 . 0 0 5}$ & \\
A260 & F & $\mathbf{1 3 8 . 7 7 6}$ & $\mathbf{4 3 . 7 3 9}$ & $\mathbf{1 8 . 4 1 6}$ & $\mathbf{4 . 4 6 5}$ & 118 \\
& p & $<\mathbf{0 . 0 0 1}$ & $<\mathbf{0 . 0 0 1}$ & $<\mathbf{0 . 0 0 1}$ & $\mathbf{0 . 0 3 7}$ & \\
DOC & F & $\mathbf{9 2 . 9 2 2}$ & $\mathbf{1 5 . 8 7 4}$ & $\mathbf{5 . 4 7 5}$ & 2.79 & 108 \\
& p & $<\mathbf{0 . 0 0 1}$ & $<\mathbf{0 . 0 0 1}$ & $\mathbf{0 . 0 2 1}$ & 0.098 & \\
$\mathrm{NH}_{4}$ & F & $\mathbf{2 8 . 7 8 1}$ & 0.03 & 1.827 & 0.002 & 120 \\
& p & $<\mathbf{0 . 0 0 1}$ & 0.864 & 0.179 & 0.96 & \\
$\mathrm{Amino} \mathrm{N}$ & $\mathrm{F}$ & $\mathbf{4 6 . 8 4 9}$ & 1.781 & 0.005 & 1.009 & 121 \\
& p & $<\mathbf{0 . 0 0 1}$ & 0.185 & 0.943 & 0.317 & \\
$\mathrm{PO}_{4}$ & $\mathrm{~F}$ & $\mathbf{2 4 8 . 9 0 6}$ & 1.637 & $\mathbf{5 . 5 5 1}$ & 1.296 & 120 \\
& p & $<\mathbf{0 . 0 0 1}$ & 0.203 & $\mathbf{0 . 0 2}$ & 0.257 & \\
$\mathrm{CO}_{2}$ & $\mathrm{~F}$ & $\mathbf{1 3 . 6 3 4}$ & $\mathbf{8 0 . 0 1 5}$ & 0.265 & $\mathbf{5 . 8 3 3}$ & 66 \\
& $\mathrm{P}$ & $<\mathbf{0 . 0 0 1}$ & $<\mathbf{0 . 0 0 1}$ & 0.609 & $\mathbf{0 . 0 1 9}$ & \\
$\mathrm{CH}_{4}$ & $\mathrm{~F}$ & $\mathbf{2 6 . 5 6 6}$ & $\mathbf{9 8 . 0 5 3}$ & 0.19 & 3.046 & 55 \\
& $\mathrm{P}$ & $<\mathbf{0 . 0 0 1}$ & $<\mathbf{0 . 0 0 1}$ & 0.664 & 0.087 & \\
\hline
\end{tabular}

Table 4. Grand means (and standard errors) in flooding and unflooded treatment areas before (2006-2007), during (2008-2009, shaded) and after (2010) flooding treatment.

\begin{tabular}{|c|c|c|c|c|c|c|c|c|}
\hline \multirow[b]{2}{*}{ year } & \multicolumn{2}{|c|}{$\mathrm{pH}$} & \multicolumn{2}{|c|}{ ORP (mV) } & \multicolumn{2}{|c|}{$\mathrm{Fe}^{3+}(\mu \mathrm{M})$} & \multicolumn{2}{|c|}{ A260nm (AU) } \\
\hline & unflooded & flooded & unflooded & flooded & unflooded & flooded & unflooded & flooded \\
\hline 2006 & $5.14(0.04)$ & $4.89(0.07)$ & $-152.7(66.2)$ & $-142.0(79.3)$ & $178.6(8.8)$ & $165.3(6.0)$ & $0.276(0.019)$ & $0.238(0.023)$ \\
\hline 2007 & $3.86(0.22)$ & $3.54(0.22)$ & nd & nd & $476.1(15.3)$ & 337.9 (19.9) & $0.308(0.067)$ & $0.303(0.129)$ \\
\hline 2008 & $4.82(0.08)$ & $5.00(0.15)$ & $180.0(20.8)$ & $112.5(28.5)$ & $58.9(7.2)$ & 74.7 (10.4) & $0.958(0.217)$ & $1.380(0.592)$ \\
\hline 2009 & $4.62(0.02)$ & $5.23(0.04)$ & $237.9(6.4)$ & $124.3(10.7)$ & 34.5 (6.9) & $44.3(9.6)$ & $0.224(0.022)$ & $0.446(0.070)$ \\
\hline 2010 & $5.20(0.20)$ & $4.67(0.22)$ & $124.8(34.8)$ & 220.9 (18.2) & 183.7 (10.6) & $74.9(8.6)$ & $0.394(0.071)$ & $0.232(0.071)$ \\
\hline
\end{tabular}

Soil pore water samples were assayed for the presence of siderophores on a single day (8 July) in 2009 (Fig. 5d). In a two-way ANOVA, the concentration of siderophores was much higher in low elevation areas $(F=38.9, P<0.001)$ and there was no significant effect of flooding. The same pattern held in 2010 (data not shown), and including data for both 2009 and 2010, siderophore concentrations were highly positively correlated with total dissolved Fe (correlation coefficient $r=0.931, n=44)$ and A260 ( $r=0.862, n=33)$, and negatively correlated with ORP $(r=-0.751, n=26)$.

$\mathrm{PO}_{4}$ was significantly higher in the flooded treatment but the effect of topography was not significant (Fig. 5e, Table 3). There was no significant effect of topography or flooding on amino-N in soil pore water (Fig. 5f, Table 3). Neither were there consistent effects of flooding or topography on $\mathrm{NH}_{4}^{+}$
(Table 3). The higher grand means for $\mathrm{NH}_{4}^{+}$concentrations in the flooding treatment (Fig. 5g) were due to higher values early in the summer (Fig. 5h), leading to a significant date $\times$ flooding interaction in the three-way ANOVA with date coded categorically $(P=0.031)$. $\mathrm{NO}_{3}^{-}$concentrations were below detection limits $(\sim 5 \mu \mathrm{M})$ in the majority of water samples, and the mean $\mathrm{NO}_{3}^{-}$concentrations for flooded and unflooded treatments were nearly identical (4.9 vs. $5.1 \mu \mathrm{M}$, respectively; data not shown).

Dissolved $\mathrm{CH}_{4}$ and $\mathrm{CO}_{2}$ concentrations were correlated with each other and with A260, DOC and Fe(III) (Table 1). Like most of the other soil water variables, dissolved $\mathrm{CO}_{2}$ also declined throughout the season (Fig. 6a). Dissolved $\mathrm{CH}_{4}$ followed a different seasonal pattern, peaking in midsummer (Fig. 6b). Because of this, the three-way ANOVA 

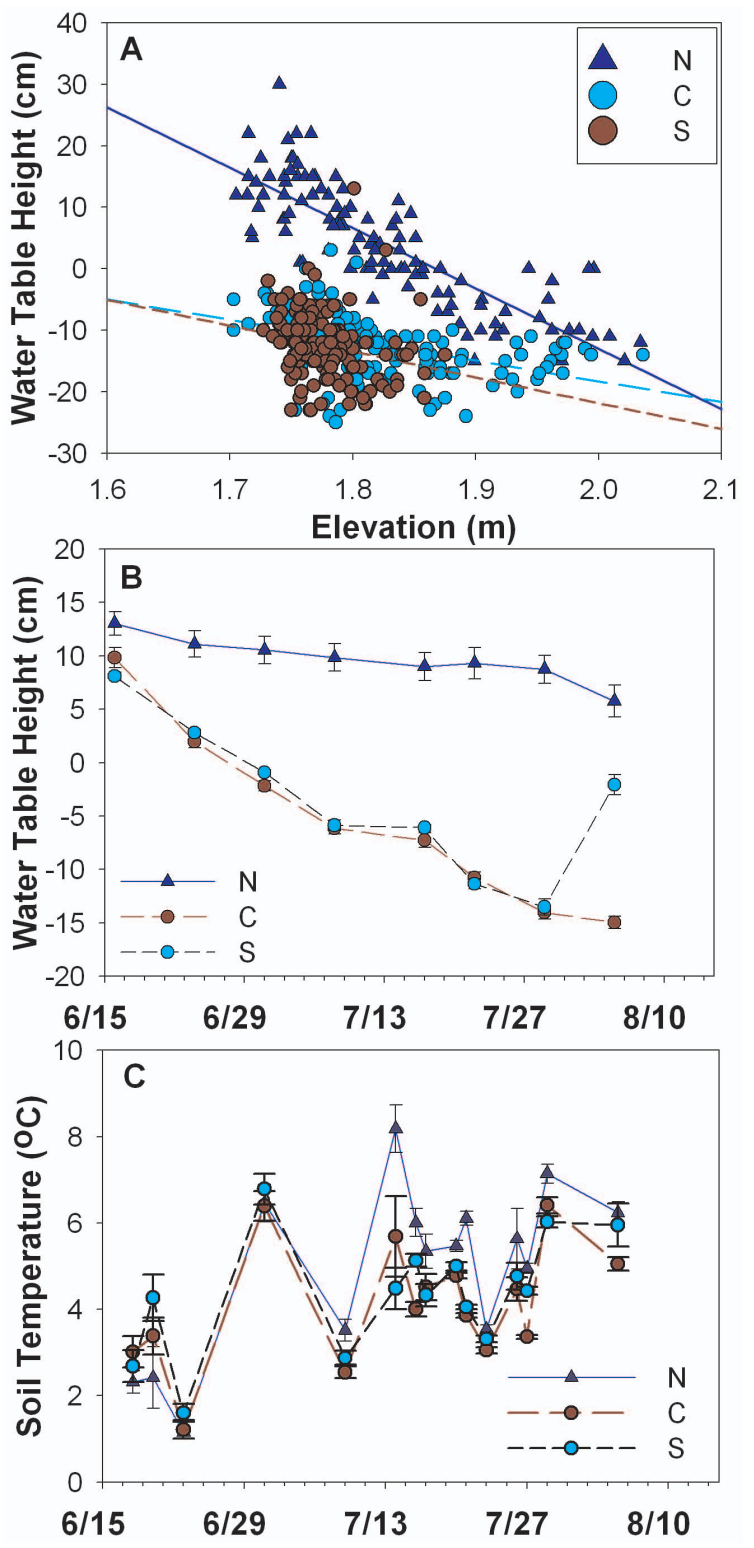

Fig. 1. (A) The relationship between water table depth and elevation, and the effects of flooding the North transect $(\mathrm{N})$. Data are shown for 21-29 July 2009. Points with elevation below $1.7 \mathrm{~m}$ were omitted, as this elevation class existed only in the North transect. (B) Seasonal changes in water-table height in the three treatment areas. (C) Soil temperature at $10 \mathrm{~cm}$ (measurements associated with $\mathrm{pH}$ and ORP measurements across each transect, generally made between 10 a.m. and 6 p.m).

of dissolved $\mathrm{CH}_{4}$ with date coded categorically had significantly lower $\mathrm{AIC}_{c}$ than the ANCOVA with date coded as a continuous variable (Table 3). At a depth of $0-5 \mathrm{~cm}$, both $\mathrm{CO}_{2}$ and $\mathrm{CH}_{4}$ were found in significantly higher concentrations in topographically low areas (Fig. 6a, b). Across all dates, the flooding treatment significantly lowered dissolved $\mathrm{CO}_{2}$ concentrations in high elevation areas (Topo $\times$ Flood interaction in Table 3, Fig. 6 ); the similar trend for $\mathrm{CH}_{4}$
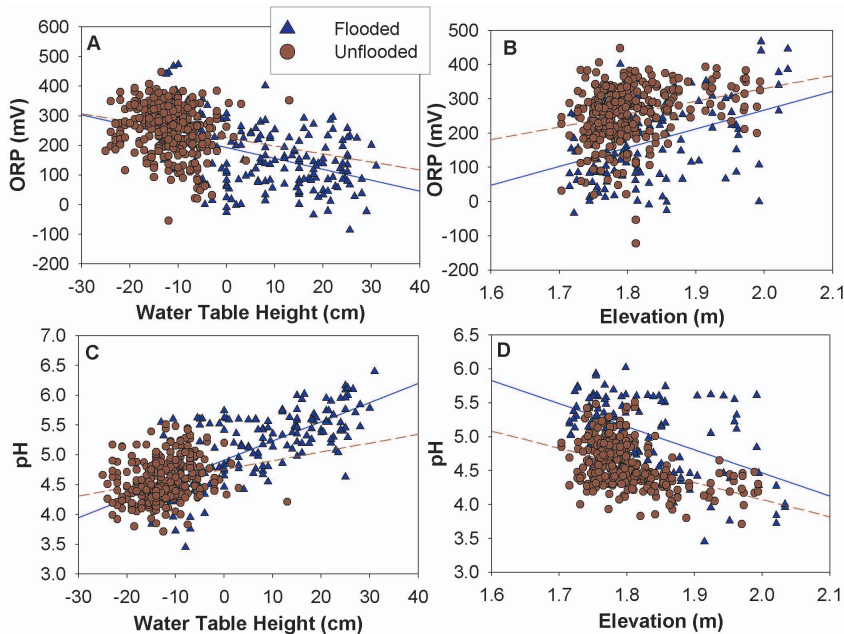

Fig. 2. Relationships of oxidation-reduction potential (ORP) and $\mathrm{pH}$ with water-table height and elevation. (A) ORP vs. water table; (B) ORP vs. elevation; (C) $\mathrm{pH}$ vs. water table; (D) $\mathrm{pH}$ vs. elevation. Data are shown for 17-29 July 2009. For the plots showing relationships with elevation, data were omitted for elevations $<1.7 \mathrm{~m}$, which only occurred in the flooded transect. ORP values are relative to a $\mathrm{Ag} / \mathrm{AgCl}$ reference electrode.

(Fig. 6b) was marginally significant ( $P=0.087$, Table 3 ).

On one day towards the end of summer (1 August 2009), higher dissolved $\mathrm{CO}_{2}$ and $\mathrm{CH}_{4}$ concentrations were observed in low elevation areas of the flooding treatment. This led to marginally significant date $\times$ flooding interactions $(P=$ 0.067 and 0.063 for $\mathrm{CO}_{2}$ and $\mathrm{CH}_{4}$ ). This change in the effect of the flooding treatment coincided with a period when water tables in the control areas were rapidly dropping to nearminimum levels (Fig. 1b); the flooding treatment appears to have extended conditions favorable for $\mathrm{CH}_{4}$ and $\mathrm{CO}_{2}$ accumulation later into the season. On this day only (by happenstance), water samples were also collected from $5-15 \mathrm{~cm}$ depth at the same locations and analyzed for dissolved $\mathrm{CO}_{2}$ and $\mathrm{CH}_{4}$ (Fig. 6c, d). A three-way ANOVA was run using topography, depth and flooding as factors $(\mathrm{dfe}=28)$. For $\mathrm{CH}_{4}$, concentrations were significantly higher at depth $(F=16.1$, $P<0.001)$, in low elevation areas $(F=22.9, P<0.001)$ and in the flooding treatment $(F=11.1, P=0.002)$, and the topography $\times$ flooding interaction was also significant $(F=5.3, P=0.029)$, indicating that the flooding response was driven by low elevation areas. For $\mathrm{CO}_{2}$, the effects of flooding $(F=8.2, P=0.008)$, topography $(F=31.7$, $P<0.001)$ and depth $(F=32.7, P<0.001)$ were significant, as was the topography $\times$ flooding interaction $(F=9.4$, $P=0.005)$, indicating the differential effect of flooding on high vs. low areas, and the depth $\times$ topography interaction ( $F=5.5, P=0.027)$, stemming from the steeper depth gradient in topographically high areas. (A steeper gradient along the profile implies more rapid diffusion in high elevation areas). 

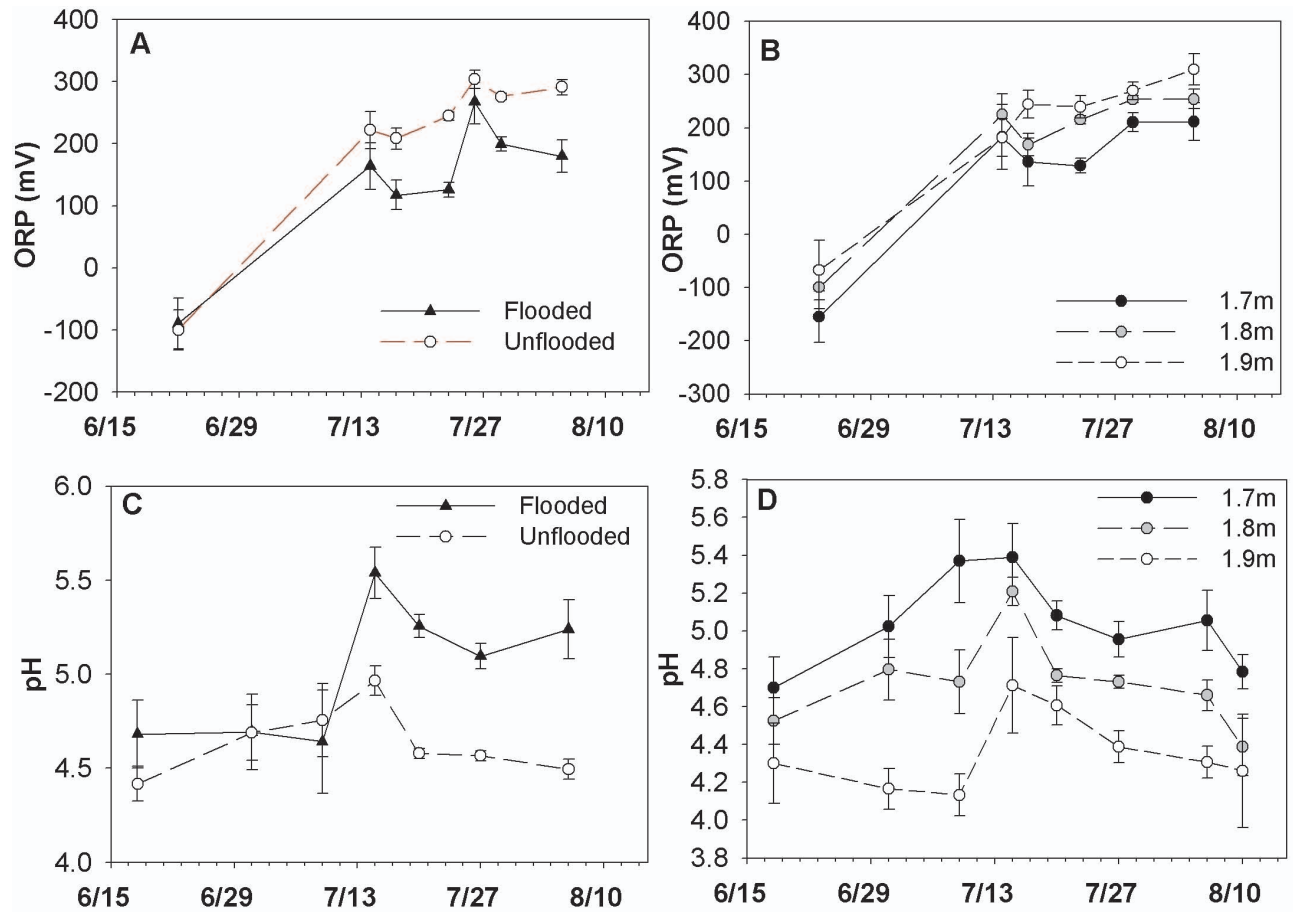

Fig. 3. Seasonal trends in 2009 for (A) ORP by flooding treatment, (B) ORP by elevation class, (C) $\mathrm{pH}$ by flooding treatment and (D) $\mathrm{pH}$ by elevation class. Elevation classes were defined by rounding elevation values to the nearest $0.1 \mathrm{~m}$. All electrochemical and temperature readings were taken at $10 \mathrm{~cm}$ depth. $\mathrm{ORP}$ values are relative to an internal $\mathrm{Ag} / \mathrm{AgCl}$ reference electrode.

Table 5. Geometric means (and geometric standard errors) of the $\mathrm{CH}_{4}: \mathrm{CO}_{2}$ ratio dissolved in soil pore water collected at two depths and in emissions from anaerobic laboratory incubations of soils. Means are separated by flooding treatment, microtopography (high vs. low) and sampling date. The standard errors are multiplicative, meaning the mean multiplied and divided by the error corresponds to the mean \pm standard error of the log-transformed data.

\begin{tabular}{lccccc}
\hline & \multicolumn{2}{c}{ Unflooded } & \multicolumn{2}{c}{ Flooded } \\
& Date & High & Low & High & Low \\
\hline Dissolved & & & & & \\
$0-5 \mathrm{~cm}$ & $6 / 29 / 2009$ & $325.4(1.39)$ & $136.2(1.33)$ & $217.6(1.09)$ & $99.4(1.36)$ \\
& $7 / 19 / 2009$ & $90.0(1.20)$ & $18.1(1.19)$ & $96.3(1.26)$ & $39.4(1.18)$ \\
& $8 / 1 / 2009$ & $652.2(1.18)$ & $407.6(1.56)$ & $508.3(1.13)$ & $116.2(1.05)$ \\
& $8 / 11 / 2009$ & $485.9(1.19)$ & $305.6(1.08)$ & $536.8(1.15)$ & $276.7(1.64)$ \\
$5-15 \mathrm{~cm}$ & $8 / 1 / 2009$ & $419.2(1.60)$ & $215.7(1.37)$ & $218.0(1.57)$ & $59.6(1.50)$ \\
Incubations & & & & & \\
& $6 / 29 / 2009$ & $957.6(1.77)$ & $360.6(1.58)$ & $732.0(1.62)$ & $99.5(1.72)$ \\
& $7 / 14 / 2009$ & $2118.3(1.29)$ & $232.5(1.61)$ & $713.6(2.47)$ & $30.4(1.29)$ \\
& $8 / 3 / 2009$ & $1753.0(1.67)$ & $372.8(1.35)$ & $686.6(1.25)$ & $44.7(1.49)$ \\
\hline
\end{tabular}

Ratios of dissolved $\mathrm{CO}_{2}: \mathrm{CH}_{4}$ were quite high for a wet and low oxygen landscape, but generally followed predictable patterns, decreasing in the most anoxic areas (Table 5). This variable was log-normally distributed and so values are expressed as geometric means, and a three-way ANOVA was run on log-transformed data (in $0-5 \mathrm{~cm}$ samples), with date, flooding and topography as factors. The
$\mathrm{CO}_{2}: \mathrm{CH}_{4}$ ratio varied by date, dropping in mid-July when $\mathrm{CH}_{4}$ concentrations peaked $(F=41.1, P<0.001)$, and was greater in high areas of the landscape $(F=37.7, P<0.001)$. Overall, the flooding treatment was not significant, but the flooding $\times$ date interaction was $(F=2.9, P=0.042)$, indicating an inconsistent effect of flooding throughout the season. Analyzing each date separately, the increase in 


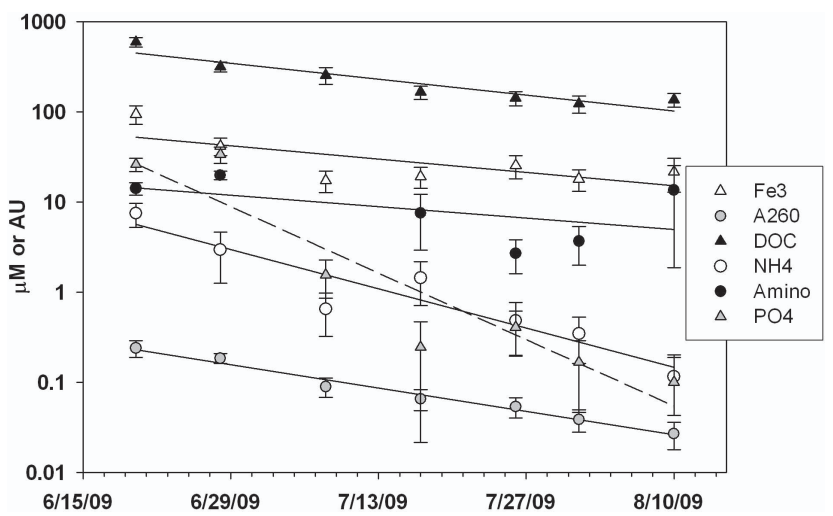

Fig. 4. Seasonal patterns of dissolved ion concentration $(\mu \mathrm{M})$ and degree of UV absorbance (absorbance units, AU) in soil pore water collected from $0-5 \mathrm{~cm}$ depth in 2009 . Values are means and standard errors of both treatments and topographic types. The Y-axis is shown on a logarithmic scale.

$\mathrm{CO}_{2}: \mathrm{CH}_{4}$ ratio in flooded areas on 7/19/2009 and the decrease in flooded areas on 8/1/2009 were both marginally significant $(P=0.061$ and $P=0.05$, respectively). On $8 / 1 / 2009$ (the day on which both shallow and deeper samples were analyzed), depth $(F=5.3, P=0.028)$, topography $(F=10.1, P=0.003)$ and flooding $(F=9.388, P=0.004)$ were all significant.

Many soil chemistry variables responded in concert to natural and experimental changes in water-table height, as seen in the intercorrelations of $\mathrm{A} 260, \mathrm{Fe}(\mathrm{III}), \mathrm{CO}_{2}$, and $\mathrm{CH}_{4}$; their positive correlations with $\mathrm{pH}$ and their negative correlations with ORP (Table 1). Furthermore, the logarithm of dissolved $\mathrm{Fe}(\mathrm{III})$ was positively correlated with the height of the water table $(r=0.369, n=119, P<0.001)$, in a regression that incorporated both seasonal and spatial variation. Interestingly, while $\mathrm{Fe}(\mathrm{III})$ and $\mathrm{CH}_{4}$ pore water concentrations were positively correlated (because both increase with anoxia), the logarithm of dissolved $\mathrm{CH}_{4}$ concentration was negatively correlated with the ratio of $\mathrm{Fe}^{3+} /$ total $\mathrm{Fe}$ (Fig. $7 ; R^{2}=0.406, F=14.2, P<0.001$ ). This relationship was significant while controlling for the effect of topography $(F=21.8, P<0.001)$, and the slopes were not significantly different between high and low topographic types $(F=1.598, P=0.21)$. This indicates that this negative relationship was not mediated solely by $\mathrm{O}_{2}$ (inasmuch as the topographic types control for variation in $\mathrm{O}_{2}$ ), and so a direct relationship might exist between dissolved $\mathrm{CH}_{4}$ and the average oxidation state of the soluble Fe pool.

\subsection{Microbial activity and biomass}

Consistent with the effects of flooding and microtopography on ORP and DO shown above, anaerobic microbial processes also responded to natural and experimental variations in water-table height (Fig. 8). Potential $\mathrm{CO}_{2}$ and $\mathrm{CH}_{4}$ pro-
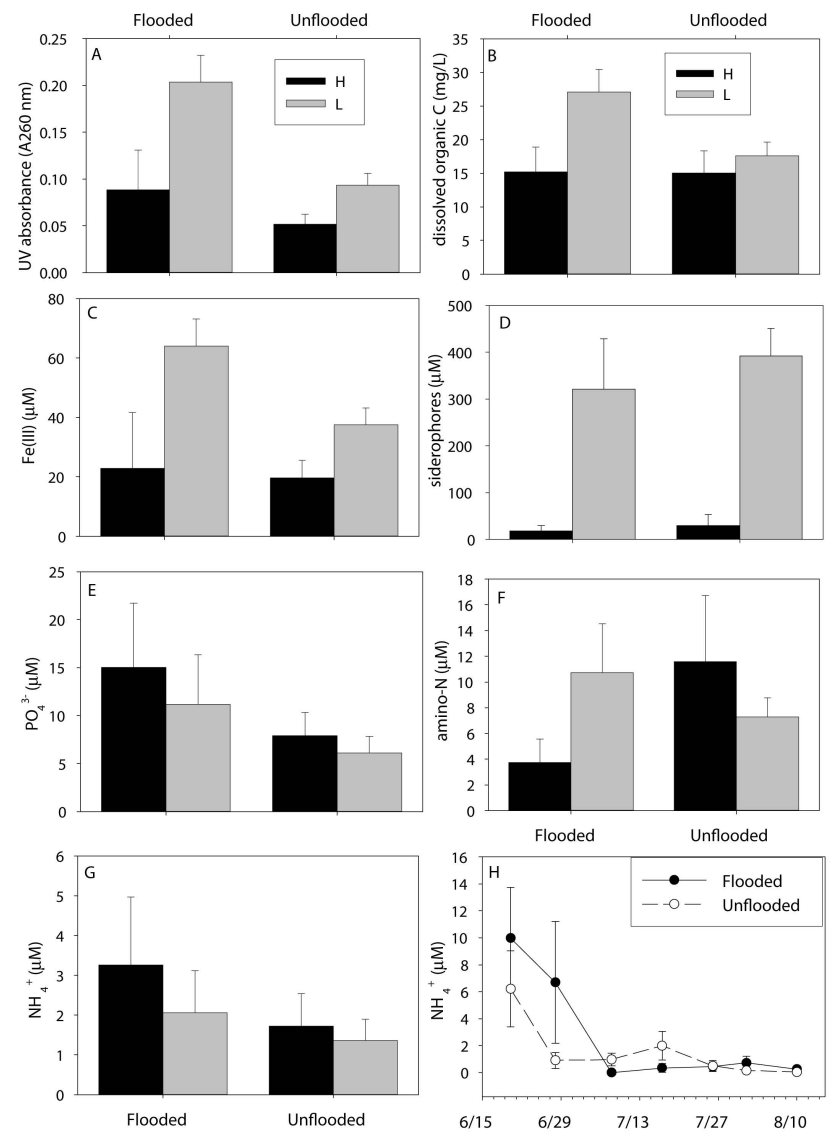

Fig. 5. Soil pore water chemistry extracted from upper $5 \mathrm{~cm}$ of soil in summer, 2009. (A-G) Grand means of all samples dates in summer 2009 in topographically high and low areas of flooded and unflooded treatments. Siderophore concentrations are presented as $\mu \mathrm{M}$ deferoxamine equivalents. (H) Seasonal trends for $\mathrm{NH}_{4}^{+}$in flooded and unflooded treatments. Refer to Table 3 and the text for statistical significance.

duction rates were measured in anaerobic laboratory incubations on three dates, and effects were tested using a threeway ANOVA with date, topography and flooding as factors. $\mathrm{CO}_{2}$ production rates in anaerobic incubations were highest on the first date $(P=0.003)$, and consistently greater in high topography regions of the flooding treatment (Fig. 8a, topography $\times$ flooding interaction: $P=0.019)$. The direct topographic $(P=0.018)$ and flooding $(P=0.003)$ effects were also significant, but both appear to be driven by high areas in the flooding treatment. In other words, the potential for anaerobic respiration mainly responded to flooding in the high regions, presumably because microbial communities in low regions were already predisposed to anaerobic respiration. $\mathrm{CH}_{4}$ production rates in these incubations were greater in low elevation areas and in the flooding treatment $(P<0.001$ for both; date and interactions not significant, Fig. 8b). The $\mathrm{CO}_{2}: \mathrm{CH}_{4}$ ratios evolved in incubations were similar to those dissolved in soil pore water, and showed 

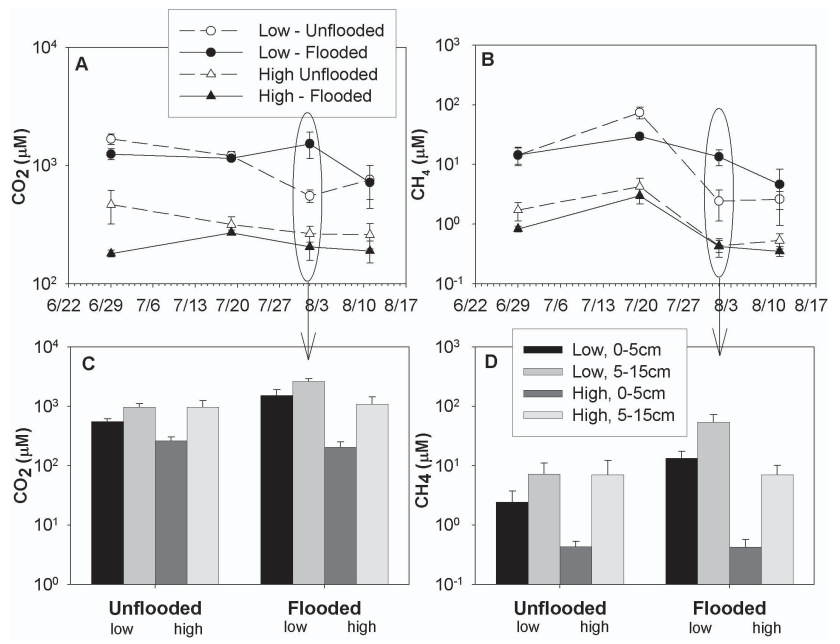

Fig. 6. Dissolved gases in soil pore water from high and low areas within flooded and unflooded treatments: (A) $\mathrm{CO}_{2}$ and (B) $\mathrm{CH}_{4}$ at a depth of 0-5 cm over four dates in 2009; (C) $\mathrm{CO}_{2}$ and (D) $\mathrm{CH}_{4}$ at $0-5 \mathrm{~cm}$ and $5-15 \mathrm{~cm}$ depth on 1 August 2009. The Y-axes are scaled logarithmically. Refer to Table 3 and the text for statistical significance.

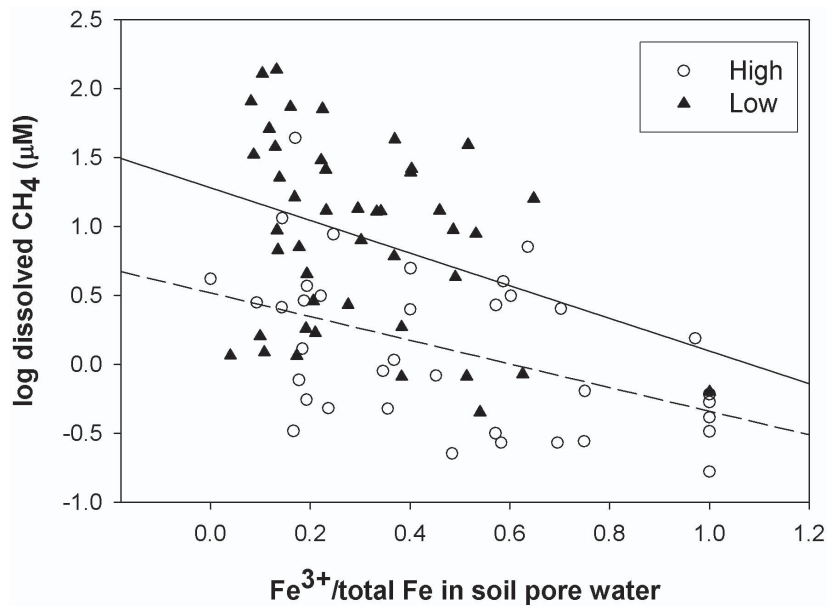

Fig. 7. Relationship between concentration of $\mathrm{CH}_{4}$ (logtransformed) and the ratio of $\mathrm{Fe}^{3+}$ to total $\mathrm{Fe}$ dissolved in soil pore water in topographically high and low areas. Separate regression lines are shown for low (solid) and high (dashed).

similar spatial patterns (Table 5). $\mathrm{CO}_{2}: \mathrm{CH}_{4}$ was reduced in flooded areas $(F=19.5, P<0.001)$ and in topographically low areas $(F=51.8, P<0.001)$. Differences among dates were not significant in this analysis.

Dissimilatory Fe(III) reduction over the course of the summer was monitored as changes in the reduction state of $\mathrm{Fe}$ bearing minerals in the soil. Acid-extractable Fe(III) declined throughout the season as $\mathrm{Fe}(\mathrm{II})$ increased, indicating net $\mathrm{Fe}$ reduction (Fig. 8c). There was significantly more acid-extractable $\mathrm{Fe}$ (II) in low areas of the landscape
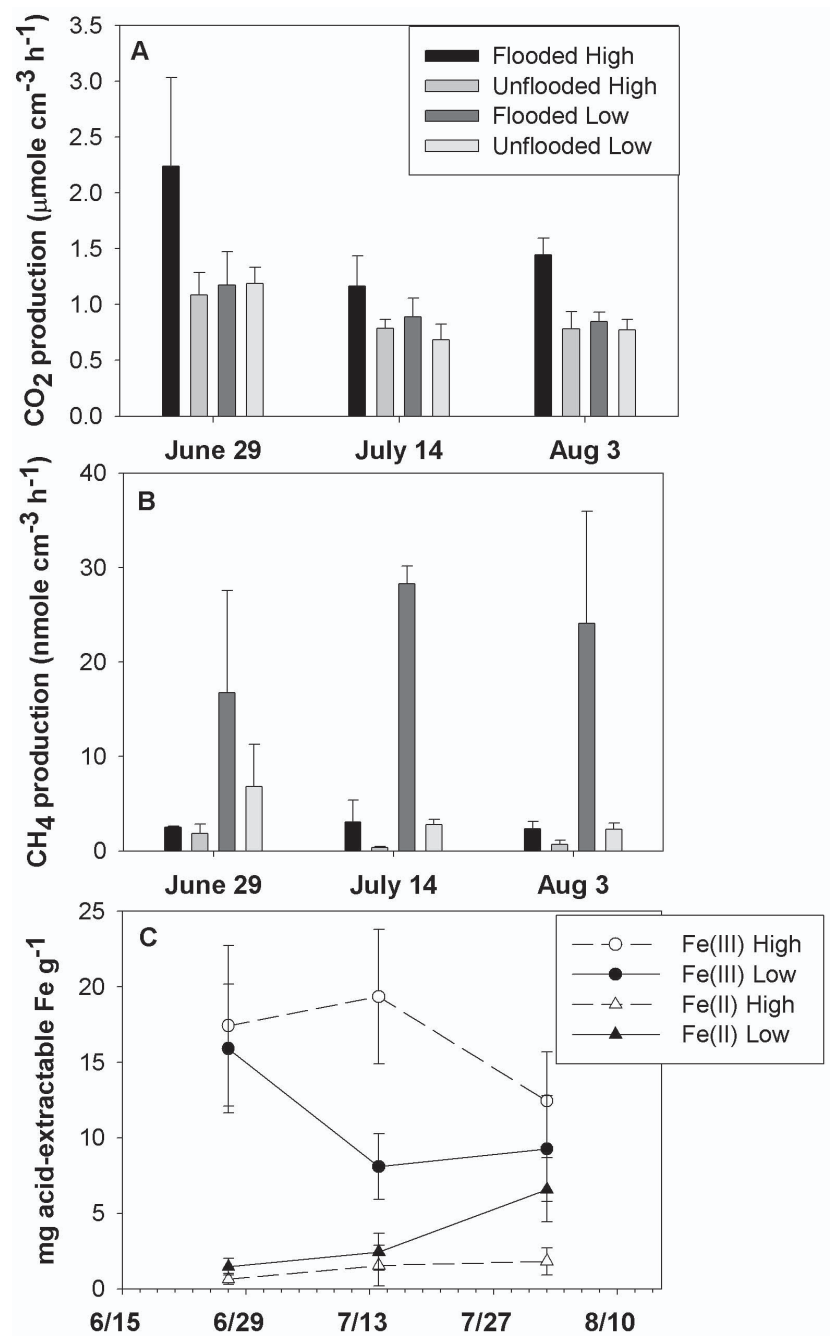

Fig. 8. Indicators of anaerobic processes in soils collected in 2009. Production rates of $(\mathbf{A}) \mathrm{CO}_{2}$ and $(\mathbf{B}) \mathrm{CH}_{4}$ in anaerobic laboratory incubations of soil from flooded and non-flooded treatments. (C) Seasonal changes in acid-extractable Fe(III) and Fe(II) from high and low areas of the landscape.

$(P=0.015)$. Flooding effects were not statistically significant. Seasonal Fe reduction rates calculated from either the increase in $\mathrm{Fe}$ (II) or the decrease in $\mathrm{Fe}$ (III) in the acid soluble fraction were greater in low elevation areas (high: 6.4 27.4 mmole Fe m ${ }^{-2} \mathrm{~d}^{-1}$; low: $28.0-36.4$ mmole Fe $\mathrm{m}^{-2} \mathrm{~d}^{-1}$, with low and high ranges based on $\Delta \mathrm{Fe}(\mathrm{II})$ and $\Delta \mathrm{Fe}(\mathrm{III})$, respectively).

In contrast to these measures of anaerobic activity, more general measures of microbial biomass showed more subtle responses to water table. Microbial biomass $\mathrm{C}$, measured by fumigation-extraction, showed no significant effects of flooding, topography or date (Fig. 9a). Microbial biomass $\mathrm{N}$ (measured as ninhydrin-active $\mathrm{N}$ released by fumigation extraction) showed marginally significant effects driven by lower means in flooded, low-elevation areas in 


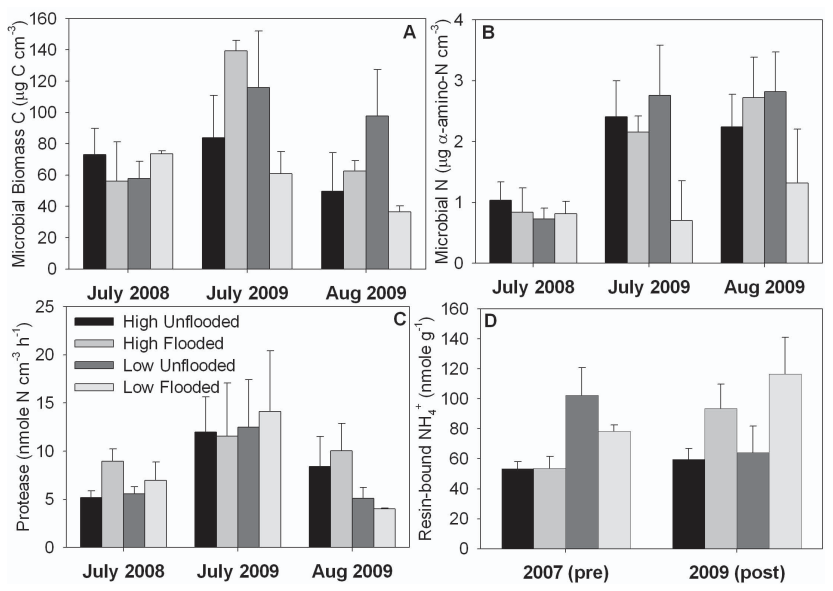

Fig. 9. Measures of microbial biomass and N cycling in soils collected from high and low areas of flooded and unflooded areas: (A) Microbial biomass $\mathrm{C}$ and (B) ninhydrin-active $\mathrm{N}$ measured by the fumigation-extraction method, (C) potential proteolysis rates, and (D) $\mathrm{NH}_{4}^{+}$bound to buried resin bags over the 2007 (pre-flooding) and 2009 (post-flooding) seasons.

2009 (Fig. 9b). In a GLM analysis $($ dfe $=44)$, date was significant $(F=9.106, P<0.001)$, the flooding effect $(F=$ $3.252, P=0.078)$ and the topography $\times$ flooding interaction $(F=3.215, P=0.080)$ were marginally significant, and the direct topography effect was not significant $(F=1.687$, $P=0.201)$.

Soil protease activity varied by date $(P=0.016)$, but flooding and topographic effects were not significant (Fig. 9c). In contrast, $\mathrm{N}$ availability integrated over the summer appeared to respond to water-table height: more $\mathrm{N}$ was captured by buried resin bags in low elevation areas during the pre-flooding year (2007) and in the flooding treatment in 2009 (Fig. 9d). In the three-way ANOVA comparing year, treatment area, and topography $(\mathrm{dfe}=30)$, topography $(F=4.421, P=0.044)$ and the year $\times$ transect interaction $(F=5.218, P=0.030)$ were significant. (This interaction indicates the effect of flooding, which occurred in 2009, but not 2007).

\section{Discussion}

Being a relatively flat area with drainage blocked by permafrost and a climate with generally low evaporative demand, this ecosystem is subject to regular flooding from snow melt. Therefore, experimental flooding mainly accentuated the normally occurring responses to seasonal and spatial variation in water-table height. Microtopography arising from ice wedge polygons controlled spatial variation in water-table height, leading to sharp contrasts in soil chemistry and microbiology over short spatial scales. The effects of the flooding treatment recovered quickly after the water table manipulation ended: during the flooding treat-

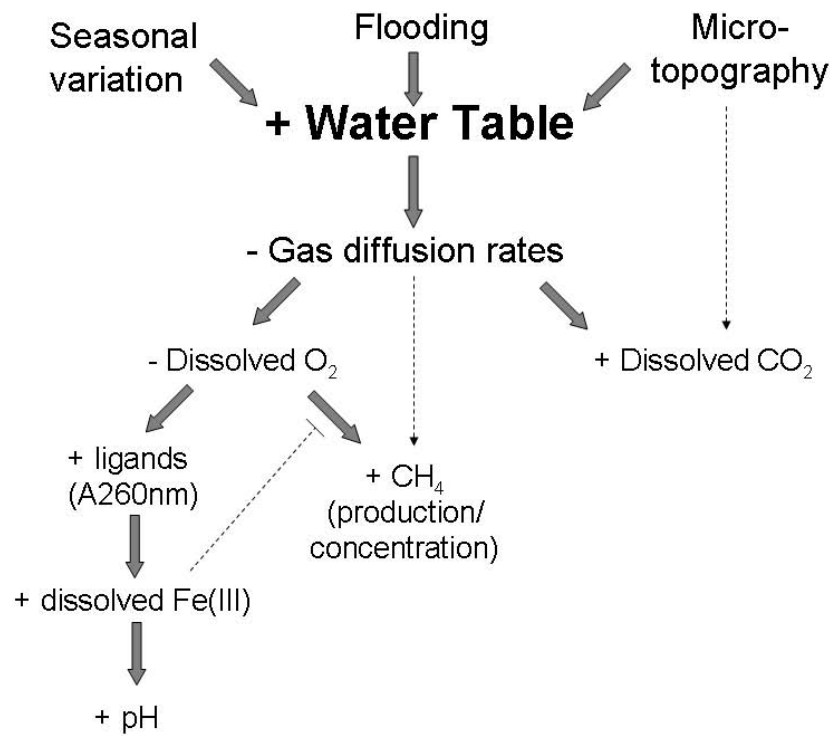

Fig. 10. Synthesis of major results from this paper, illustrating possible mechanisms by which water table affected the measured variables. The dotted flat arrow from $\mathrm{Fe}$ (III) to $\mathrm{CH}_{4}$ indicates a possible negative effect.

ment ORP was lower and $\mathrm{pH}, \mathrm{Fe}(\mathrm{III})$ and A260 were higher in the flooded section compared to the unflooded sections, but these trends reversed in 2010 after the flooding treatment had ended. In the absence of the experimental manipulation, the less polygonized southern end of the basin was more reducing, on average, than the more polygonized northern section. Increased polygonization leads to a greater abundance of elevated, oxic areas within the landscape, which raised the overall average ORP of the landscape.

Many of the observed effects of natural and experimental variation in water-table height can be attributed to lower diffusion rates of gases in wet soils (Fig. 10). Inundated areas become anoxic, and the microbial communities appear to respond by producing organic ligands that solubilize $\mathrm{Fe}(\mathrm{III})$. The process of solubilizing and reducing $\mathrm{Fe}$ (III) (as well as other alternative $\mathrm{e}^{-}$acceptors) consumes protons, leading to higher pH (Reddy and DeLaune, 2008). Conversely, protons are released and $\mathrm{pH}$ is lowered under oxidizing conditions; this was seen dramatically in 2007 (Table 4), an exceptionally dry year in which water-table height dropped to much lower levels then in other years of the study (Olivas et al., 2010). Flooded, anoxic conditions also promote the growth and activity of methanogens, and lower diffusion rates can also trap more $\mathrm{CH}_{4}$ in the soil. However, the increased availability of $\mathrm{Fe}(\mathrm{III})$ could competitively inhibit methane production (Roden and Wetzel, 1996; Bond and Lovley, 2002; Küsel et al., 2008; Jerman et al., 2009), weakening these effects (dotted flat arrow in lower left, Fig. 10). High water tables also slow diffusion of $\mathrm{CO}_{2}$ out of the soil, leading to higher concentrations in lower, wetter areas. It is also 
possible that microtopographic patterns of plant growth and litter accumulation contribute to higher dissolved $\mathrm{CO}_{2}$ concentrations in polygon centers (dotted arrow in upper right, Fig. 10) (Zona et al., 2011). Root respiration from vascular plants such as Carex aquatilis, which are more prevalent in the lower areas, could also contribute to this trend. Conversely, submerged stems of Sphagnum spp., dominant in higher parts of the landscape, may efficiently draw down dissolved $\mathrm{CO}_{2}$ (Rydin and Clymo, 1989).

The inference that microbes solubilize Fe(III) in response to anoxia is based on (1) the surprisingly high concentrations of $\mathrm{Fe}(\mathrm{III})$ in soil pore water, given only moderately acidic conditions, best explained by the presence of organic chelating agents; (2) the high concentrations of siderophores in pore water of low, anoxic areas; and (3) the strong correlations among soluble Fe, siderophores, the UV absorbance of soil pore water (A260) and ORP. Aromatic compounds, including several classes of siderophores (Drechsel and Jung, 1998), strongly absorb UV wavelengths. The presence of Fe can also enhance the UV absorbance of solutions (Weishaar et al., 2003), though the correlations of A260 with DOC and siderophores show that the relationship between Fe(III) and A260 was not produced entirely by this effect.

It has already been established that the process of $\mathrm{Fe}(\mathrm{III})$ reduction is important in this ecosystem (Lipson et al., 2010). However, the present study shows the importance of this process in shaping fine scale patterns of soil chemistry. This is expressed in the solubilization of $\mathrm{Fe}$ (III) in response to anoxic conditions, and the inverse microtopographic patterns of redox conditions and $\mathrm{pH}$, indicating that protonconsuming reactions such as $\mathrm{Fe}(\mathrm{III})$ reduction take place where reducing conditions predominate. Furthermore, it was not known how the prevalence of $\mathrm{Fe}(\mathrm{III})$ reduction impacts $\mathrm{CH}_{4}$ production in this ecosystem. The high ratios of $\mathrm{CO}_{2}: \mathrm{CH}_{4}$ dissolved in soil pore water and produced in anaerobic laboratory incubations indicate an ecosystem with an abundance of alternative $\mathrm{e}^{-}$acceptors for anaerobic respiration (Updegraff et al., 1995; van Hulzen et al., 1999; Keller and Bridgham, 2007; Keller et al., 2009). In the absence of alternative $\mathrm{e}^{-}$acceptors, roughly equimolar concentrations of $\mathrm{CO}_{2}$ and $\mathrm{CH}_{4}$ would be produced (i.e., a ratio of one), whereas values observed in incubations and dissolved in soil pore water were generally orders of magnitude higher. Hence, even in the most anoxic areas of the landscape, methanogenesis still constituted a minor fraction of metabolic $\mathrm{e}^{-}$flow (at least for the surface layers studied here). The negative relationship between dissolved $\mathrm{CH}_{4}$ concentrations and the oxidation state of the soluble Fe pool $\left(\mathrm{Fe}^{3+} /\right.$ total $)$ shown in Fig. 7 provides further evidence that methanogenesis is competitively inhibited by alternative $\mathrm{e}^{-}$ acceptors. $\mathrm{O}_{2}$ is probably the primary control over dissolved $\mathrm{CH}_{4}$ in the surface layers, as can be seen in the lower $\mathrm{CH}_{4}$ concentrations and higher $\mathrm{CO}_{2}: \mathrm{CH}_{4}$ ratios in raised, more oxic areas of the landscape. Likewise, the average oxidation state of $\mathrm{Fe}$ is higher in oxic areas. However, the same negative relationship between $\mathrm{CH}_{4}$ and $\mathrm{Fe}^{3+}$ /total exists for both high and low areas, indicating a direct relationship between these variables rather than one that is purely mediated by $\mathrm{O}_{2}$. The oxidation state of the dissolved Fe pool could be interpreted as a measure of $\mathrm{Fe}(\mathrm{III})$ availability for dissimilatory $\mathrm{Fe}$ reduction, as the tendency for $\mathrm{Fe}(\mathrm{III})$ reduction given by the Nernst equation depends on the ratio of oxidized and reduced Fe. However, it is also true that chelated Fe reacts rapidly with soil humic substances and so various $\mathrm{Fe}(\mathrm{III})$ chelates have been used to measure the oxidation state and "reduction capacity" of humic acids in laboratory incubations (Peretyazhko and Sposito, 2006). Our soils are novel in having high concentrations of chelated $\mathrm{Fe}(\mathrm{III})$ in soil pore water, and so the oxidation state of the dissolved Fe pool might provide an in situ measure of the oxidation state of the humic substances in contact with this soluble Fe pool. If this is the case, then the negative relationship shown in Fig. 7 might be caused by preferential use of oxidized humic substances as terminal $\mathrm{e}^{-}$acceptors for anaerobic respiration over methanogenesis, as seen in other studies (Cervantes et al., 2000; Heitmann et al., 2007). Addition of the humic ana$\log$, AQDS, stimulated respiration in laboratory incubations of soils from this ecosystem (Lipson et al., 2010), showing that quinones found in humic substances can serve as terminal $\mathrm{e}^{-}$acceptors in these soils.

The availability of alternative $\mathrm{e}^{-}$acceptors (Fe(III) and/or humic substances) and the high $\mathrm{CO}_{2}: \mathrm{CH}_{4}$ ratios explain why reported $\mathrm{CH}_{4}$ fluxes from this landscape (24.6 $\mathrm{mg} \mathrm{CH}_{4} \mathrm{~m}^{-2} \mathrm{~d}^{-1}$ ) (Zona et al., 2009) are near the low end for those reported in the Arctic (Blodau, 2002; Wagner et al., 2003). And so in terms of climate change, the potential for increased methane production from ecosystems such as the DTLB studied here could be limited by the high availability of Fe(III) and humic substances. This inhibitory effect could be enhanced if deeper thaw leads to mobilization of $\mathrm{Fe}$ from the mineral layers that currently reside in the upper permafrost of many DTLB's of the Arctic Coastal Plain (Hinkel et al., 2003).

The results of this study indicate that microbial communities in much of this landscape are dominated by facultative and/or strict anaerobes. It was mainly in high elevation areas (e.g., polygon rims), where conditions were normally oxic near the surface for most of the year, where the potential for anaerobic respiration responded to the flooding treatment (Fig. 8a), indicating that anaerobically-respiring microbes were already abundant in low areas of the landscape. Methanogens, being strict anaerobes that thrive in the most reducing conditions, responded more dramatically to the flooding treatment and showed a marked preference for low elevation areas, where the risk of exposure to $\mathrm{O}_{2}$ is lower (Fig. 8b). This landscape pattern has been noted in other studies (Wagner et al., 2003; Strack and Waddington, 2007). There were only the subtlest of hints that flooding might create suboptimal conditions for microbial activity: lower dissolved $\mathrm{CO}_{2}$ concentrations in flooded, topographically high 
areas could have been caused by a depression of respiration due to suboxic conditions (Fig. 6a). Microbial biomass C was not impacted by flooding, though one could argue that the statistically weak decrease in microbial biomass $\mathrm{N}$ in low elevation areas of the flooding treatment represented a negative microbial response to flooding. However, there was no consistent trend toward lower microbial biomass $\mathrm{C}$ or $\mathrm{N}$ in lower elevation areas, indicating that anoxic conditions do not generally limit the biomass of the local microbial community. Flooding experiments in northern peat soils have often produced insignificant or relatively minor effects on ecosystem respiration (Updegraff et al., 2001; Chivers et al., 2009; Huemmrich et al., 2010), while lowering water table tends to have more dramatic effects (Oechel et al., 1998; Strack et al., 2006; Strack and Waddington, 2007; Sommerkorn, 2008). This dichotomy is understandable given the tendency of these ecosystems toward waterlogged, suboxic conditions. Increases in soil $\mathrm{CO}_{2}$ fluxes with lowered water tables is generally attributed to increased $\mathrm{O}_{2}$ availability (Billings et al., 1982; Sommerkorn, 2008; Olivas et al., 2010). While $\mathrm{O}_{2}$ certainly plays a major role, the impressive capacity for anaerobic respiration of some peat soils should not be overlooked. At our study site, the flooded treatment area was submerged under water for nearly the entire 2008 growing season, and yet chamber-based measurements of ecosystem respiration (ER) were only $23 \%$ less than those measured in the control area, where the water table was generally below the surface (Olivas et al., 2010). Moreover, landscape scale measurements of net ecosystem $\mathrm{CO}_{2}$ exchange and estimation of ER from eddy covariance showed that the flooded area lost $\mathrm{CO}_{2}$ more quickly with higher wind speed (Zona et al., 2012). Similarly, eddy covariance measurements of $\mathrm{CH}_{4}$ fluxes from this ecosystem also showed strong effects of wind speed (Sturtevant et al., 2011). These wind-driven fluxes would not be captured by chamber measurements and so the decrease in ER reported with flooding (Olivas et al., 2010) may have been over-estimated. Our observation in the current study of high dissolved $\mathrm{CO}_{2}$ concentrations in low, wet areas and steeper $\mathrm{CO}_{2}$ concentration gradients in higher, drier areas suggests that the effects of soil water on diffusion rates of $\mathrm{CO}_{2}$ should be considered when interpreting the effects of water table on measurements of ecosystem respiration.

The increased concentrations of $\mathrm{P}$ seen in the flooded treatment could be caused by redox-mediated release of $\mathrm{P}$ occluded in ferric hydroxides, as has been observed in other studies (Chambers and Odum, 1990; Shenker et al., 2005). However, if this were the case, one would expect to see higher dissolved $\mathrm{P}$ in topographically low areas. The lack of response of soluble $\mathrm{P}$ to topography makes this explanation less likely. The nutrient cycling effects might also be explained by the temperature/thaw depth aspect of the flooding treatment. The largest increases in nutrient concentrations were shortly after break up, before soil temperatures had warmed in response to the flooding treatment. The in- creases in $\mathrm{N}$ and $\mathrm{P}$ concentrations observed in the flooding treatments early in 2009 could have been partly caused by the release of labile substrates from permafrost due to the increased thaw depth in 2008 (Shiklomanov et al., 2010). The increased $\mathrm{N}$ bound to buried resin bags could have also have been a result of increased soil temperatures in the current year leading to greater rates of $\mathrm{N}$ mineralization. In high Arctic regions of continuous permafrost, where thermokarsting is leading to expansion of flooded areas (Smith et al., 2005), warming and flooding could have a positive interactive effect on nutrient availability. This flush of nutrients could stimulate plant production, partially offsetting $\mathrm{C}$ losses from permafrost (Shaver et al., 1992), but it could also ultimately stimulate decomposition and further loss of soil C (Mack et al., 2004).

The observed pulse of nutrients after snow melt is commonly reported in arctic, alpine and other cold ecosystems (Chapin et al., 1978; Zak et al., 1990; Brooks et al., 1998; Lipson et al., 1999; Edwards et al., 2006). Maximum thaw depths occur in late summer after plants have already begun to senesce (Olivas et al., 2010) and so nutrients made available from thawing of permafrost might not be accessible to plants until the following break up. The rapid decline after snow melt of dissolved nutrients probably represents rapid uptake by plants, as drainage from the basin is blocked by permafrost and little water is lost to run-off (Hinkel et al., 2001). This early season pulse has long been hypothesized to represent a major contribution to plant nutrient requirements in Arctic coastal tundra (Chapin et al., 1978), and such a pattern would help plants capitalize on nutrients mobilized from recently thawed permafrost.

\section{Summary and conclusions}

The flooding treatment produced two distinct suites of results: (1) elevated water-table heights led to more reducing conditions, stimulating siderophore production and the solubilization and reduction of $\mathrm{Fe}(\mathrm{III})$; (2) Flooding stimulated $\mathrm{N}$ and $\mathrm{P}$ availability, probably due to warmer temperatures and deeper active layer depths. This study provides evidence that methanogenesis is inhibited in this ecosystem by the availability of $\mathrm{Fe}$ (III) and humic substances as alternative $\mathrm{e}^{-}$acceptors for anaerobic respiration. This study also demonstrates how dissimilatory $\mathrm{Fe}(\mathrm{III})$ reduction interacts with ice wedge polygon-induced microtopography to shape landscape patterns of soil chemistry and microbiology.

Acknowledgements. The authors wish to thank Faustine Bernadac, Steve Hastings, Louis Brower and many others from BASC and CPS for logistical support, Maria Santos for assistance in the field, and Ling Han and Dominic Goria for assistance in laboratory analysis. The work was funded by NSF grants OPP-0421588 to W.C.O. and ARC-0808604 to D.A.L.

Edited by: P. Stoy 


\section{References}

Alexander, B. and Zuberer, D. A.: Use of chrome azurol S reagents to evaluate siderophore production by rhizosphere bacteria, Biol.Fertil. Soils, 39-45, 1991.

Analytical Methods Committee: Standardized general method for the determination of iron with 1,10-phenanthroline, Analyst, 103, 391-396, 1978.

Bartlett, R. J. and Ross, D. S.: Colorimetric determination of oxidizable carbon in acid soil solutions, Soil Sci. Soc. Am. J., 52, 1191-1192, 1988.

Billings, W. D. and Peterson, K. M.: Vegetational change and icewedge polygons through the thaw-lake cycle in arctic Alaska., Arctic Alpine Res., 12, 413-432, 1980.

Billings, W. D., Lukens, J. O., Mortensen, D. A., and Peterson, K. M.: Arctic tundra: A source or sink for atmospheric carbon dioxide in a changing environment?, Oecologia 53, 7-11, 1982.

Blodau, C.: Carbon cycling in peatlands - A review of processes and controls, Environ. Rev. 10, 111-134, 2002.

Bloom, A. A., Palmer, P. I., Fraser, A., Reay, D. S., and Frankenberg, C.: Large-scale controls of methanogenesis inferred from methane and gravity spaceborne data, Science, 327, 322-325, 2010.

Bockheim, J., Hinkel, K., Eisner, W., and Dai, X.: Carbon pools and accumulation rates in an age-series of soils in drained thaw-lake basins, Arctic Alaska, Soil Sci. Soc. Am. J., 68, 697-704, 2004.

Bond, D. and Lovley, D.: Reduction of Fe(III)) oxide by methanogens in the presence and absence of extracellular quinones, Environ. Microbiol., 4, 115-124, 2002.

Brooks, P. D., Williams, M. W., and Schmidt, S. K.: Inorganic nitrogen and microbial biomass dynamics before and during spring snowmelt, Biogeochemistry, 43, 1-15, 1998.

Brown, J.: Tundra soils formed over ice wedges, northern Alaska, Soil Sci. Soc. Am. Proc., 31, 686-691, 1967.

Cervantes, F., van der Velde, S., Lettinga, G., and Field, J.: Competition between methanogenesis and quinone respiration for ecologically important substrates in anaerobic consortia, FEMS Microbiol. Ecol., 34, 161-171, 2000.

Chambers, R. M. and Odum, W. E.: Porewater oxidation, dissolved phosphate and the iron curtain Iron-phosphorus relations in tidal freshwater marshes, Biogeochemistry, 10, 37-52, 1990.

Chapin, F.S., Barsdate, R.J. and Barèl, D.: Phosphorus cycling in Alaskan coastal tundra: a hypothesis for the regulation of nutrient cycling, Oikos 31, 189-199, 1978.

Chivers, M. R., Turetsky, M. R., Waddington, J. M., Harden, J. W., and McGuire, A. D.: Effects of experimental water table and temperature manipulations on ecosystem $\mathrm{CO}_{2}$ fluxes in an Alaskan rich fen, Ecosyst., 12, 1329-1342, 2009.

Drechsel, H. and Jung, G.: Peptide Siderophores, J. Pept. Sci., 4, 147-181, 1998.

Edwards, K. A., McCulloch, J., Kershaw, G. P., and Jefferies, R. L.: Soil microbial and nutrient dynamics in a wet Arctic sedge meadow in late winter and early spring, Soil Biol. Biochem., 38, 2843-2851, 2006.

Heitmann, T., Goldhammer, T., Beer, J., and Blodau, C.: Electron transfer of dissolved organic matter and its potential significance for anaerobic respiration in a northern bog, Glob. Change Biol., 13, 1771-1785, 2007.

Hinkel, K., Paetzold, F., Nelson, F., and Bockheim, J.: Patterns of soil temperature and moisture in the active layer and upper per- mafrost at Barrow, Alaska: 1993-1999, Global Planet. Change 29, 293-309, 2001.

Hinkel, K. M., Eisner, W. R., Bockheim, J. G., Nelson, F. E., Peterson, K. M., and Dai, X.: Spatial extent, age, and carbon stocks in drained thaw lake basins on the Barrow Peninsula, Alaska, Arct. Antarct. Alp. Res., 35, 291-300, 2003.

Huemmrich, K. F., Kinoshita, G., Gamon, J. A., Houston, S., Kwon, H., and Oechel, W. C.: Tundra carbon balance under varying temperature and moisture regimes, J. Geophys. Res., 115, G00I02, doi:10.1029/2009JG001237, 2010.

IPCC: Summary for Policymakers, Climate Change 2007: The Physical Science Basis. Contribution of Working Group I to the Fourth Assessment Report of the Intergovernmental Panel on Climate Change, edited by: Solomon, S., Qin, D., Manning, M., Chen, Z., Marquis, M., Averyt, K. B., Tignor, M., and Miller, H. L., Cambridge University Press, Cambridge, United Kingdom and New York, NY, USA, 2007.

Jerman, V., Metje, M., Mandić-Mulec, I., and Frenzel, P.: Wetland restoration and methanogenesis: the activity of microbial populations and competition for substrates at different temperatures, Biogeosciences, 6, 1127-1138, doi:10.5194/bg-6-11272009, 2009.

Keller, J. K. and Bridgham, S. D.: Pathways of anaerobic carbon cycling across an ombrotrophic-minerotrophic peatland gradient, Limnol. Oceanogr. 52, 96-107, 2007.

Keller, J. K., Weisenhorn, P. B., and Megonigal, J.P.: Humic acids as electron acceptors in wetland decomposition, Soil Biol. Biochem., 41, 1518-1522, 2009.

Kögel-Knabner, I., Amelung, W., Cao, Z., Fiedler, S., Frenzel, P., Jahn, R., Kalbitz, K., Kölbl, A. and Schloter, M.: Biogeochemistry of paddy soils, Geoderma, 157, 1-14, 2010.

Kujala, K., Seppälä, M., and Holappa, T.: Physical properties of peat and palsa formation, Cold Reg. Sci. Technol., 52, 408-414, 2008.

Kuo, S.: Phosphorus, in: Methods of Soil Analysis, Part 3: Chemical Methods, edited by: Sparks, D. L., American Society of Agronomy, Madison, WI, 869-920, 1996.

Küsel, K., Blöthe, M., Schulz, D., Reiche, M., and Drake, H. L.: Microbial reduction of iron and porewater biogeochemistry in acidic peatlands, Biogeosciences, 5, 1537-1549, doi:10.5194/bg-5-1537-2008, 2008.

Lipson, D. A., Schmidt, S. K., and Monson, R. K.: Links between microbial population dynamics and $\mathrm{N}$ availability in an alpine ecosystem, Ecology, 80, 1623-1631, 1999.

Lipson, D. A., Jha, M., Raab, T. K., and Oechel, W. C.: Reduction of iron (III) and humic substances plays a major role in anaerobic respiration in an Arctic peat soil, J. Geophys. Res.-Biogeosci, 115, G00I06, doi:10.1029/2009JG001147, 2010.

Mack, M. C., Schuur, E. A. G., Bret-Harte, M. S., Shaver, G. R., and Chapin, F. S.: Ecosystem carbon storage in arctic tundra reduced by long-term nutrient fertilization, Nature 431, 440-443, 2004.

O'Donnell, J. A., Romanovsky, V. E., Harden, J. W., and McGuire, A. D.: The effect of moisture content on the thermal conductivity of moss and organic soil horizons from black spruce ecosystems in interior Alaska, Soil Sci., 174, 646-651, 2009.

Oechel, W. C., Vourlitis, G. L., Hastings, S. J., Ault, R. P., and Bryant, P.: The effects of water table manipulation and elevated temperature on the net $\mathrm{CO}_{2}$ flux of wet sedge tundra ecosystems, Glob. Change Biol., 4, 77-90, 1998. 
Oechel, W. C., Hastings, S. J., Vourlitis, G. L., Jenkins, M., Riechers, G., and Grulke, N.: Recent Change of Arctic tundra ecosystems from a net carbon dioxide sink to a source, Nature 361, 520-523, 1993

Oechel, W. C., Vourlitis, G. L., Hastings, S. J., Zulueta, R. C., Hinzman, L., and Kane, D.: Acclimation of ecosystem $\mathrm{CO}_{2}$ exchange in the Alaskan Arctic in response to decadal climate warming, Nature, 406, 978-981, 2000.

Olivas, P. C., Oberbauer, S. F., Tweedie, C. E., Oechel, W. C., and Kuchy, A.: Responses of $\mathrm{CO}_{2}$ flux components of Alaskan Coastal Plain tundra to shifts in water table, J. Geophys. Res., 115, G00I05, doi:10.1029/2009JG001254, 2010.

Peretyazhko, T. and Sposito, G.: Reducing capacity of terrestrial humic acids, Geoderma 137, 140-146, 2006.

Reddy, K. R. and DeLaune, R. D.: Biogeochemistry of wetlands: science and applications, CRC Press, Boca Raton, FL, 2008.

Rhew, R. C., Teh, Y. A., and Abel, T.: Methyl halide and methane fluxes in the northern Alaskan coastal tundra, J. Geophys. Res., 112, G02009, doi:02010.01029/02006JG000314, 2007.

Roden, E. E. and Wetzel, R. G.: Organic carbon oxidation and suppression of methane production by microbial Fe(III)oxide reduction in vegetated and unvegetated freshwater wetland sediments, Limnol. Oceanogr., 41, 1733-1748, 1996.

Rydin, H. and Clymo, R. S.: Transport of Carbon and Phosphorus Compounds about Sphagnum, Proc. R. Soc. Lond. B, 237, 63 84, 1989.

Schuur, E. A. G., Bockheim, J., Canadell, J. G., Euskirchen, E., Field, C. B., Goryachkin, S. V., Hagemann, S., Kuhry, P., Lafleur, P. M., Lee, H., Mazhitova, G., Nelson, F. E., Rinke, A., Romanovsky, V. E., Shiklomanov, N., Tarnocai, C., Venevsky, S., Vogel, J. G., and Zimov, S. A.: Vulnerability of permafrost carbon to climate change: implications for the global carbon cycle, BioScience, 58, 701-714, 2008.

Shaver, G. R., Billings, W. D., Chapin, F. S., Giblin, A. E., Nadelhoffer, K. J., Oechel, W. C., and Rastetter, E. B.: Global change and the carbon balance of arctic ecosystems, BioScience, 42, 433-441, 1992.

Shenker, M., Seitelbach, S., Brand, S., Haim, A., and Litaor, M. I.: Redox reactions and phosphorus release in re-flooded soils of an altered wetland, Eur. J. Soil Sci., 56, 515-525, 2005.

Shiklomanov, N. I., Streletskiy, D. A., Nelson, F. E., Hollister, R. D., Romanovsky, V. E., Tweedie, C. E., Bockheim, J. G., and Brown, J.: Decadal variations of active-layer thickness in moisture-controlled landscapes, Barrow, Alaska, J. Geophys. Res., 115, G00I04, doi:10.1029/2009JG001248, 2010.

Smith, L. C., Sheng, Y., MacDonald, G. M., and Hinzman, L. D.: Disappearing Arctic lakes, Science 308, 1429, 2005.

Sommerkorn, M.: Micro-topographic patterns unravel controls of soil water and temperature on soil respiration in three Siberian tundra systems, Soil Biol. Biochem., 40, 1792-1802, 2008.

Strack, M. and Waddington, J.: Response of peatland carbon dioxide and methane fluxes to a water table drawdown experiment, Global Biogeochem. Cy., 21, GB1007, doi:1010.1029/2006GB002715, 2007.
Strack, M., Waddington, J., Rochefort, L., and Tuittila, E.: Response of vegetation and net ecosystem carbon dioxide exchange at different peatland microforms following water table drawdown, J. Geophys. Res-Biogeosci., 111, G02006, doi:10.1029/2005JG000145, 2006

Sturtevant, C. S., Oechel, W. C., Zona, D., and Emerson, C. E.: Soil moisture control over autumn season methane flux, Arctic Coastal Plain of Alaska, Biogeosciences Discuss., 8, 6519-6554, doi:10.5194/bgd-8-6519-2011, 2011.

Tarnocai, C., Canadell, J. G., Schuur, E. A. G., Kuhry, P., Mazhitova, G., and Zimov, S.: Soil organic carbon pools in the northern circumpolar permafrost region, Global Biogeochem. Cy., 23, GB2023, doi:2010.1029/2008GB003327, 2009.

Updegraff, K., Pastor, J., Bridgham, S. D., and Johnston, C. A.: Environmental and substrate controls over carbon and nitrogen mineralization in northern wetlands, Ecol. Appl., 5, 151-163, 1995.

Updegraff, K., Bridgham, S. D., Pastor, J., Weishampel, P., and Harth, C.: Response of $\mathrm{CO}_{2}$ and $\mathrm{CH}_{4}$ Emissions From Peatlands to Warming And Water Table Manipulation, Ecol. Appl., 11, 311-326, 2001.

van Hulzen, J. B., Segersa, R., van Bodegoma, P. M., and Leffelaar, P. A.: Temperature effects on soil methane production: an explanation for observed variability, Soil Biol. Biochem., 31, 19191929, 1999.

von Fischer, J. C., Rhew, R. C., Ames, G. M., Fosdick, B K., and von Fischer, P. E.: Vegetation height and other controls of spatial variability in methane emissions from the Arctic coastal tundra at Barrow, Alaska, J. Geophys. Res., 115, G00I03, doi:10.1029/2009JG001283, 2010.

Wagner, D., Kobabe, S., Pfeiffer, E.-M., and Hubberten, H.-W.: Microbial controls on methane fluxes from a polygonal tundra of the Lena Delta, Siberia, Permafrost Periglac. Process., 14, 173-185, 2003.

Weishaar, J. L., Aiken, G. R., Bergamaschi, B., Fram, M. S., Fujii, R., and Mopper, K.: Evaluation of specific ultraviolet absorbance as an indicator of the chemical composition and reactivity of dissolved organic carbon, Environ. Sci. Tech., 37, 4702-4708, 2003.

Zak, D. R., Groffman, P. M., Pregitzer, K. S., Christensen, S., and Tiedje, J. T.: "The vernal dam: plant-microbe competition for nitrogen in northern hardwood forests", Ecology, 71, 651-656., 1990.

Zona, D., Lipson, D., Zulueta, R., Oberbauer, S. and Oechel, W.: Micro-topographic controls on ecosystem respiration in the Arctic tundra, J. Geophys. Res., J. Geophys. Res., 116, G00I08, doi:10.1029/2009JG001241, 2011.

Zona, D., Oechel, W. C., Kochendorfer, J., Paw U, K. T., Salyuk, A. N., Olivas, P. C., Oberbauer, S. F., and Lipson, D. A.: Methane fluxes during the initiation of a large-scale water table manipulation experiment in the Alaskan Arctic tundra, Global Biogeochem. Cy., 23, GB2013, doi:2010.1029/2009GB003487, 2009

Zona, D., Lipson, D. A., Barott, K., Paw-U, K. T., Oberbauer, S F., Olivas, P., Hastings, S., Hinzman, L. D. and Oechel, W. C.: Inundation increases respiration loss from the Arctic tundra, in review, 2012 